\title{
From Formal to Technical Styles: Production Challenges and Economic Implications of Changing Tableware Styles in Roman to Late Antique Sagalassos
}

\author{
ELIZABETH A. MURPHY AND JEROEN POBLOME
}

Changing tableware styles between the Roman Imperial and Late Antique periods have attracted significant attention recently, with socially constructed interpretations of consumer demand that view changing vessel shapes, sizes, and decoration in relation to communal dining practices of late antiquity. Building on that research, this study approaches such stylistic changes from the perspective of the important, yet less investigated, figure of the producer on the workshop floor. In comparing two production dumps from the tableware production center at Sagalassos (southwest Turkey), one dated to the second century C.E. and one to the late fifth to early sixth century C.E., this study identifies shifts in the technical and technological styles between the two periods that relate to changes in vessel form, size, and finishing. Having identified several critical technical changes in the Late Antique production at Sagalassos, this article then explores the degree to which changing vessel styles affected manufacturing output, production organization, and workshop economy, consequently demonstrating the dynamic response by an ancient local industry to changing technical and social contexts through several centuries of activity. Using detailed classifications and quantifications of manufacturing waste, this research also develops new methodologies for the analysis of ancient production sites. ${ }^{1}$

\section{INTRODUCTION}

Stylistic change in material culture has been a fundamental topic of archaeological inquiry. Archaeology's reliance on stylistic change in artifacts for functional and chronological attribution of archaeological contexts makes analysis of such change an essential methodological tool, yet studies of artifact style certainly have not been limited to these typo-chronological dimensions. Indeed, stylistic analyses have been used to address a wide range of questions, particularly those concerning definitions and organizations of relations between ethnic, cultural, and social groups. When considering the Roman world, much research in changing tableware styles from the Roman to Late Antique periods has emphasized their relation to consumption and

American Journal of Archaeology

Volume 121, Number 1

January 2017

Pages 61-84

DOI: $10.3764 /$ aja.121.1.0061

www.ajaonline.org

\footnotetext{
${ }^{1}$ This research was supported by the Research Fund of the Institute for the Study of the Ancient World (New York University), the Belgian program on Interuniversity Attraction Poles, the Research Fund of the University of Leuven, and the Research Foundation Flanders. We would like to give special thanks to Andrew Murphy for preparing the computer models and to Tom Leppard for painstakingly reading drafts of this article. All errors are, however, the fault of the authors. Original artifact photography was by Bruno Vandermeulen and Danny Veys (Insite Photography). Figures are by Elizabeth A. Murphy unless otherwise noted.
} 
use practices. While Swift notes that stylistic changes in vessel decoration, form, and function are intimately related to changing aesthetics, ${ }^{2}$ she and others have also suggested that transitions in ceramic shape and size between these periods may be related to changing dining practices in late antiquity. ${ }^{3}$ Emphasizing functional attributes rather than technical prowess, this perspective proposes that varying dining practices (from individual portions to shared dishes) are represented through shifting typological preferences, from small cups and bowls to large bowls and platters-an assertion further supported by depictions of elite communal dining preserved from the later period. ${ }^{4}$

Such functional attributions related to shifting dining practices have been successful in providing social interpretations for consumer demand as regards tableware styles, yet the relationship between style and technical execution is not defined by the qualities, appearance, and function of the objects alone. In fact, interpretations of these stylistic changes in Roman tableware have often hinged in part on an assessment of the technical rendering of tablewares according to a variety of criteria, including rim and wall thickness, sharp definition of the rim and base, intricate decoration, consistent application and "bright" oxidized firing of the slip, absence of surface blemishes, and symmetry of form. These criteria mostly concern what Hopper might describe as aesthetic "attention to detail" by the potter, ${ }^{5}$ rather than function-affecting design elements. Such quality-based assumptions recall early discussions on the aesthetic merits of Roman fine wares, a category exemplified by the well-known Arretine and South Gaulish sigillatas. ${ }^{6}$ Evaluations of this sort have, not coincidentally, situated the Late Antique ceramic evidence in wider narratives of the period that sometimes paint an overarching picture of economic stagnation, loss of technological knowledge, and deterioration in technical skill. ${ }^{7}$ Opposing views of late antiquity criticize such perspectives for imposing modern biases of aesthetically based stylistic choice

\footnotetext{
${ }^{2}$ Swift 2007; 2009, 107-14.

${ }^{3}$ Hawthorne 1997; Hudson 2006; Vroom 2007, 343.

${ }^{4}$ Supra n. 3. For a similar discussion, see also Cool (2006, 53 5, 152-71), who tracks the reverse changes in British serving wares (i.e., communal to individual servings) between the Late Iron Age and early Roman Imperial period.

${ }^{5}$ Hopper 2000.

${ }^{6}$ For such an example, see Charleston 1955.

${ }^{7}$ Ward-Perkins 2006, 88-92, 104-8.
}

and for undervaluing the economic and technological achievements of the period. ${ }^{8}$

Reevaluation of the relationship between aesthetic styles, consumption practices, and the technologies of production is driving new investigations based not only on an object's appearance and use through time but also on the manner in which that object is made. In this regard, execution of ceramic production can also be understood within the context of socially learned behaviors that derive from the transmission of knowledge of craft techniques (e.g., the sequences and methods of making, the motor skills necessary to execute those sequences, and the ability to adapt those methods to sometimes-variable materials) and knowledge of craft technologies (e.g., the design, use, and maintenance of objects and infrastructure used in production). Together, the techniques and technologies of craft production constitute "technological styles," as defined by Lechtman, ${ }^{9}$ and can be reconstructed archaeologically as sets of production practices maintained and transmitted within communities of artisans. It is at the junction of artifact styles and technological styles, therefore, that this study investigates changing ceramic forms and technical execution in the Roman and Late Antique periods to assess the impact of these transitions on production output and workshop economy at the site of Sagalassos.

\section{SAGALASSOS RED SLIP WARE PRODUCTION}

The industry at Sagalassos manufactured regionally distributed tablewares designated "Sagalassos Red Slip Ware," and most of its production was concentrated in the Eastern Suburbium of the ancient city. ${ }^{10}$ While numerous activities have been identified in this suburban zone, Sagalassos Red Slip Ware production is one of the most conspicuous in archaeological terms. Overfired waster sherds, broken molds, kiln stacking supports, furnace fragments, and kiln slag (i.e., the discarded remains of ceramic production) densely litter the modern surface across this 3.5-4.0 ha area,

\footnotetext{
${ }^{8}$ For critiques, see the edited volume by Lavan et al. (2007), particularly the contributions by Arthur (2007), Bonifay (2007), and Mannoni (2007) therein.

${ }^{9}$ Lechtman 1977.

${ }^{10}$ The Eastern Suburbium has also been referred to as the "Potters' Quarter" in many of the early publications from the project. Also, recently a fifth- to early sixth-century C.E. ceramic workshop was found within the city proper. It is the only example of such a placement to date (Uleners and Poblome 2014).
} 
and geophysical prospection has identified more than 80 strong magnetic anomalies associated with industrial kilns. ${ }^{11}$ Excavations in this section of the ancient city over the past 15 years have investigated eight workshops, dozens of kilns, and numerous waster dumps. Geochemical analyses have established that the Sagalassos workshops operating from Augustan to Early Byzantine times used essentially the same clay materials, ${ }^{12}$ and excavations of workshop contexts show that technologies used to fire the tableware maintained the same (simple updraft) kiln design (fig. 1). ${ }^{13}$ As the Sagalassos Red Slip Ware industry was continually active from the later first century B.C.E. to the seventh century C.E., shifts noted within the typological sequence of this ware can be interpreted more readily as stylistic changes within a local tradition. In general, therefore, the Sagalassos Red Slip Ware industry, with its long-standing production tradition and its wellpreserved archaeological record, is an ideal case study with which to investigate matters of technological and economic development during this period.

Importantly for the purposes of this study, the general typological shifts noted between the Early/Middle and Late Roman industries in other parts of the empire are also reflected in the ceramic types manufactured at Sagalassos. One such period of typological shift can be observed beginning in the second half of the fourth century C.E. At this time, the changes in product repertoire coming from the Eastern Suburbium workshops of Sagalassos coincided with some changes in the local economy. In particular, regional survey data suggest a major drop in the consumption of Sagalassos

\footnotetext{
${ }^{11}$ This calculation is based on readings from the uppermost $1.5 \mathrm{~m}$ of deposits. As the stratigraphy in the Eastern Suburbium often reaches depths of $4.0 \mathrm{~m}$, the calculation reflects only the number of anomalies in the most-recent layers. Likewise, ground truthing of the uppermost layers confirms that these anomalies represent well-preserved examples of kilns. Kilns in poor states of preservation or deconstructed kilns are not normally detected by this method. Thus, we consider this estimated kiln count to be low. For an outline of methods employed, see Martens et al. 2012.

${ }^{12}$ Ottenburgs et al. 1995; Laduron and Depuydt 1997; Degryse and Poblome 2008; Degryse et al. 2008.

${ }^{13}$ It should be noted that the earliest kilns at Sagalassos were constructed of unfired brick. All the kilns at Sagalassos appear to have been constructed of kiln-fired building tile beginning in the second century C.E. This, however, does not greatly affect the study presented here, as all the deposits under evaluation are dated after the second-century C.E. introduction of fired tile kilns.
}

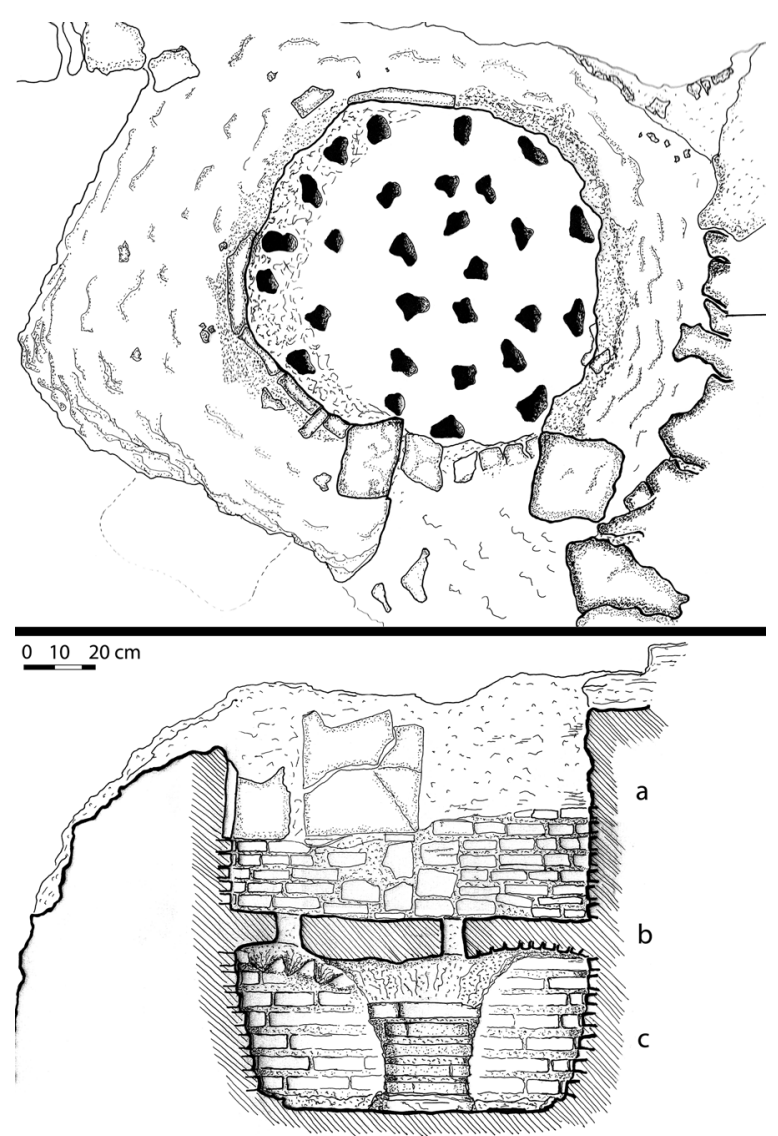

FIG. 1. Drawings (top and profile) of a simple updraft kiln found in a workshop at Sagalassos that operated from the third to the early sixth century C.E. (Sagalassos, PQEast Slope Workshop, Kiln 4): $a$, firing chamber; $b$, perforated kiln floor; $c$, combustion chamber (courtesy Sagalassos Archaeological Research Project).

Red Slip Ware in the agricultural hinterland of Sagalassos during the first half of the fourth century C.E. ${ }^{14}$ This change might be associated with the economic ramifications of Pisidian Antioch being designated as the capital of Pisidia under Diocletian around this time. ${ }^{15}$ Yet the economy of the city and its hinterland appears to have recovered by the second half of the fourth century and is characterized by several indicators of growth. Most notably, urban building projects, including the renovation of the Bath Complex, took place at this time, ${ }^{16}$ and, in the agricultural hinterland, the manufacture of a local amphora type began for the

\footnotetext{
${ }^{14}$ Poblome et al. 2013.

${ }^{15}$ Waelkens 2011.

${ }^{16}$ Supra n. 15.
} 
first time. ${ }^{17}$ Thus, the second half of the fourth century, which marked the very early introduction of some of these new types of tablewares, can be seen as part of a larger trend in the regional economy that seems to reflect renewed investment in the workshops and pottery products of the Eastern Suburbium.

These changes in Sagalassos Red Slip Ware can be characterized in general terms by comparing the repertoire of the Roman period with that of the Late Antique period. ${ }^{18}$ For instance, the Sagalassos Red Slip Ware of the first and second centuries C.E. is marked by a predominance of cups ${ }^{19}$ and bowls ${ }^{20}$ with diameters mostly about $15 \mathrm{~cm}$ and generally less than $25 \mathrm{~cm}$ (fig. 2a). ${ }^{21}$ By the late fifth to early sixth century C.E., however, these were generally replaced with larger bowls $\mathrm{s}^{22}$ and plates $^{23}$ with diameters averaging approximately $27 \mathrm{~cm}$ and generally measuring less than $35 \mathrm{~cm}$ (see fig. $2 \mathrm{~b}$ ). ${ }^{24}$ Another significant change in the assemblages of the two periods concerns the color to which the vessels were fired. While the surface coloration of vessels in both periods displays variation from a bright reddish-orange to a dark purplish-brown, those of the later period present a much higher proportion in the darker color range. ${ }^{25}$

\section{PRODUCTION WASTE}

Potters' dumps have been excavated across the Eastern Suburbium, and certain features of this waste material are particularly useful for studying production

\footnotetext{
${ }^{17}$ Poblome et al. 2008.

${ }^{18}$ Poblome 1999.

${ }^{19}$ E.g., Sagalassos Red Slip Ware Types 1A100, 1A110/1, 1A130, 1A150, and 1A160/1 (Poblome 1999).

${ }^{20}$ E.g., Sagalassos Red Slip Ware Types 1B110, 1B120, 1B150, 1B160, 1B161, 1B162, 1B163, 1B170, and 1B190/1 (Poblome 1999).

${ }^{21}$ This figure is based on the mode value of vessel diameter from the Roman Imperial-period production waste deposit analyzed later in this article.

${ }^{22}$ E.g., Sagalassos Red Slip Ware Types 1B101, 1B130, 1B171, 1B200, 1B210, 1B220/1, and 1B230, 1B231, 1B232, 1B233 (Poblome 1999).

${ }^{23}$ E.g., Sagalassos Red Slip Ware Types 1C140 and 1C180, 1C181, 1C182, 1C183 (Poblome 1999).

${ }^{24}$ This figure is based on the mode value of vessel diameter from the Late Antique production-waste deposit analyzed later in this article.

${ }^{25}$ The second-century deposit analyzed in this study contained 24\% "dark" wares, $67 \%$ "bright" wares, and 9\% with contrasting interior or exterior coloration; the sixth-century deposit exhibits 58\% "dark" wares, $31 \%$ "bright" wares, and $11 \%$ with contrasting interior or exterior coloration. The "bright" vs. "dark" distinction was delineated at a Munsell chroma reading of 8 .
}

technique. First, the quantities of material present in the workshop dumps are extraordinary. Even relatively modest samples of these deposits can easily produce thousands of sherds, making quantification-based analyses an appealing avenue of study. Second, the ceramics are of a different character than those found in other refuse deposits, particularly when compared with postconsumption refuse. These kiln-fired sherds represent objects rejected at some point in the late production or early distribution stages. Production "mistakes" or "flaws" can be therefore discerned in the data set. They offer extensive evidence for production experimentation, repairs, failures, and general problems that are only rarely observed in other types of archaeological contexts. Finally, certain types of material are really only present in significant quantity in these types of deposits - for example, kiln furniture, kiln linings and floor supports, overfired vessels, and broken tools. This is particularly salient as the excavated workshops appear to have been kept clean of many of the types of refuse found in the dumps.

Furthermore, the production-refuse dumps in the Eastern Suburbium generally appear to represent the composite accumulation from multiple workshops over a relatively short period (at least by most archaeological standards), ranging from one-half to a full century, before being covered over. The fact that these dumps represent the discard from specific workshops is inferred on the basis of slight skews in the proportional composition of certain types (and type variants) from what is common in urban deposits and the identification of several mold matches among molded objects. As products from a limited number of workshops, the remains have some consistency in the composition of material represented, while simultaneously offering a more general view on techniques used across the industrial zone at that time.

In order to investigate the relationship between changing ceramic and technological styles, deposits of production material dated to different periods from the site were selected for comparison. Archaeologists have long recognized the potential of studying production wasters to pursue these questions. For instance, Rye has noted that relative loss rates can be calculated across different forms to identify production problems, and changes to those misfiring patterns may help explain later modifications to address manufacturing "difficulties." ${ }^{26}$ The intention of this study is, therefore,

\footnotetext{
${ }^{26}$ Rye $1981,110-11$.
} 


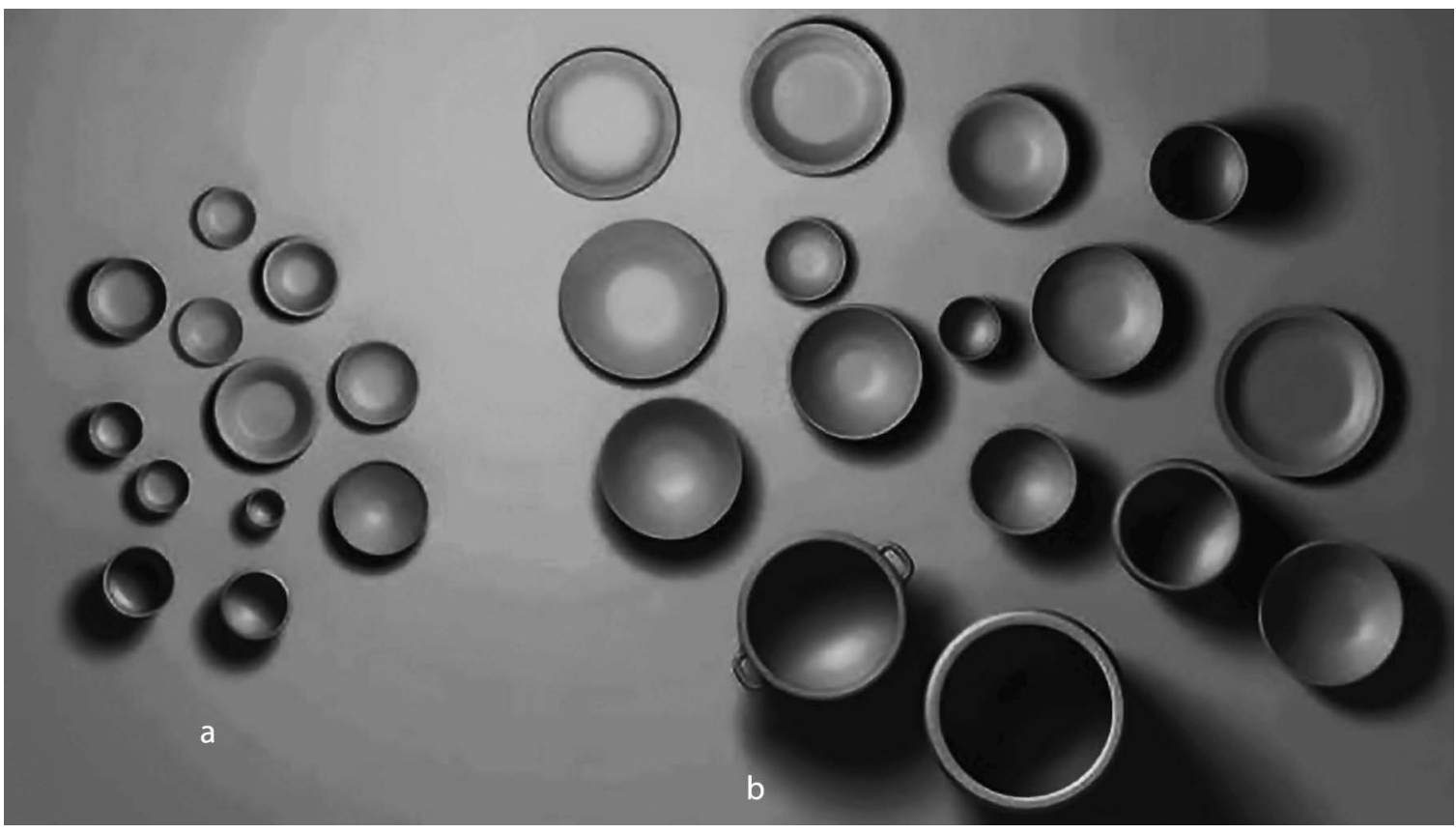

FIG. 2. Three-dimensional models of Sagalassos Red Slip Ware vessel types found in the refuse deposits: $a$, second-century C.E. assemblage; $b$, late fifth- to early sixth-century C.E. assemblage. Models prepared by Andrew Murphy.

to identify manufacturing difficulties to better understand the influence of new styles on the technical execution of pottery production.

Two deposits excavated from different sectors of Sagalassos' Eastern Suburbium were selected because they best chronologically bracket the period in question. The first is Roman Imperial in date (mid first to mid second century C.E.), and the second is Late Antique (late fifth to early sixth century C.E.). ${ }^{27}$ When important observations concerning the methods of kiln stacking were noted in the sixth-century material, a third deposit was less systematically analyzed to better understand transitional periods when certain techniques became widely employed in the industry. This third dump deposit is dated to the early fifth century C.E. ${ }^{28}$

\section{PART 1: SKILL VS. STYLE}

Both corpora of material were analyzed for evidence with which to reconstruct the production process of each vessel type represented within the data sets. In addition, irregularities in those techniques were recorded and occurrences tracked to discern repeated problems

\footnotetext{
${ }^{27}$ Sagalassos project loci SA-1997-PQ-00006 and SA-2000PQ-00002, respectively.

${ }^{28}$ Sagalassos project locus SA-1998-PQ-00037.
}

associated with specific vessel types. In general, certain segments of the process were more easily observed in the material-particularly the clay preparation, forming, and firing stages of production. In the interest of clarity, only those stages are discussed in detail here, and, as the intention is to sketch a general view of production at the site and how it changed through time, isolated examples of production techniques are likewise not described. At times, when necessary, information from contemporary workshop excavations in the Eastern Suburbium was also consulted to provide additional lines of evidence and to contextualize the dump material. ${ }^{29}$ Finally, earlier archaeometric and morphological studies of Sagalassos Red Slip Ware are cited, as applicable. While the techniques observed in these deposits provide an overview of workshops during a given period, it cannot, of course, be claimed that they are totally representative of all techniques executed at that time.

\footnotetext{
${ }^{29}$ Workshops roughly contemporaneous with our dumps have been excavated by the Sagalassos Archaeological Research Project, but there is no evidence that these workshops specifically contributed to the dumps. Preliminary publications on those workshops include Poblome et al.2001; Murphy and Poblome 2012, 2013.
} 
Types of Evidence and Their Classifications

Each of the three main types of production waste offers distinct forms of data on the production process and requires that different types of observations be recorded:

1. The sherds of Sagalassos Red Slip Ware collectively represent the most prevalent type of production waste. In most cases, however, it was not possible to infer why the vessel was rejected, as most of the fragments do not show clear defects. Nonetheless, observations were made and quantifications (counts and weights) recorded for each typologically diagnostic example concerning the following variables: fabric consistency; slip color and consistency; overall rendering of the vessel shape; trimming or turning marks; secondary applications of clay onto the vessel surface; and light scratches, scarring, and incisions into the vessel surface. ${ }^{30}$ Transitions in slip coloration at the rim, lower wall, and base were also observed and recorded according to Munsell-based color distinctions. ${ }^{31}$

2. Overfired Sagalassos Red Slip Ware provides different lines of evidence (mostly related to kiln stacking and firing). These observations include the location and orientation of fused or partially fused vessels, the orientation of drips off of the vessel, and the appearance and extent of vitrification. ${ }^{32}$ This classification is outlined in table 1 .

3. The last major body of material is kiln furniture. This subset comprises pieces of wet clay that were pressed against the vessel stacks and kiln walls to shore up the vessels during firing. When the kiln was heated, these pieces, like the vessels they supported, were fired to a hardened state, thereby preserving many impressions intact. They are referred to in this article generally as kiln spacers; categories of kiln spacers are determined according to their morphology (strips, wedges, etc.). These morphologies were dictated by the shape and part of the vessel to which they were affixed. In some cases, the impression left by the vessel on the kiln furniture is so refined that wheel marks are visible. The clays used for kiln furniture included

\footnotetext{
${ }^{30}$ Peña (2009) employed similar methodologies for studying forming and slipping techniques on African Red Slip.

${ }^{31}$ Mackensen (1993, 176-80; 2009, 28-38) employed similar methodologies for studying wasters and kiln furniture for stacking techniques used with African Red Slip Ware.

${ }^{32}$ Supra n. 26.
}

Sagalassos Fabric 1, Sagalassos "Dirty" Fabric 1 (a clay with a matrix of Fabric 1 with occasional inclusions), and Sagalassos Fabric $2 .{ }^{33}$ An outline of the spacer typology is provided in table 2; examples of spacer types are shown in figure 3 , and a reconstruction of their positioning in relation to vessels is provided in figure 4.

In general, the quantifications of these technical classifications indicated clear patterns within each of the two data sets, thereby demonstrating a consistency both in the use of certain techniques and in the problems confronting potters during a given period. Some of these techniques are observed in both periods, while others occur differentially within the two data sets or even (less commonly) are represented in one period's material exclusively. The following paragraphs outline some of the observations made when integrating the results of these three production stages, and an overview of those techniques per period is provided in table 3.

\section{Observations on the Production Process}

Clay Preparation. The first set of observations concerns clay preparation. Archaeometric and geoarchaeological studies concerning the Sagalassos Red Slip Ware clays have identified their firing properties and their places of extraction. ${ }^{34}$ Two clays were used in the manufacture of Sagalassos Red Slip Ware-one for the body fabric and another for the slip. The fabric clay has been sourced to the Çanaklı Valley systems located approximately $8 \mathrm{~km}$ to the south and $300 \mathrm{~m}$ below the workshop sites. The slip is composed of a different, ophiolitic-flysch clay that is available in the immediate vicinity of the Eastern Suburbium. These two sources were continually exploited throughout the full duration of Roman and Late Antique production at Sagalassos.

While the fabric clay from Çanakl 1 is typically quite "clean"- that is, free of nonplastic particles-inclusions are occasionally found in the matrix or crosssection of pottery from both periods. When they occurred, they sometimes caused vessel damage, more often to the Roman vessels than to the Late Antique

\footnotetext{
${ }^{33}$ Sagalassos Fabric 1 is the same clay as that used for the bodies of Sagalassos Red Slip Ware vessels. For descriptions of these fabrics, see Ottenburgs et al. 1995; Laduron and Depuydt 1997; Degryse and Poblome 2008; Degryse et al. 2008.

${ }^{34}$ Supra n. 33.
} 
TABLE 1. Abridged classification of misfired Sagalassos Red Slip Ware, highlighting the types of information derived from the different classes of ceramic misfiring.

\section{Evidence for How Vessels Were Stacked in the Kiln}

Fused stack

All vessels in the stack are the same SRSW type

Vessels in the stack are of different SRSW types

Individual misfired pieces

Discoloration zoning where another vessel touched

Location of discoloration: interior

Location of discoloration: exterior

Location of discoloration: interior and exterior

Orientation of Vessels in the Kiln

Flowing

Flow from base

Flow from rim

Indeterminate flow origin

Secondary flow drops on vessel

Degree of Vitrification (Exposure of Vessels to Heat in the Kiln)

Entirely overfired

Fire cracking

Bloating

Warping (twisted)

Squatting (downward)

Flowing (full vitrification of vessel)

Partially misfired

Light gray coring

SRSW $=$ Sagalassos Red Slip Ware

TABLE 2. Abridged classification of kiln furniture

\begin{tabular}{lll}
\hline General Morphological Class & Description & Orientation \\
\hline Vertical spacer strips & $\begin{array}{l}\text { strips with rim impressions running perpendicular to } \\
\text { their length } \\
\text { strips with rim impressions running parallel to their } \\
\text { length }\end{array}$ & vertical \\
Horizontal spacer strips & thick, curved strips with a triangular cross-section & horizontal \\
Wedges & rolled coil of clay folded into a spiral & horizontal \\
Coil & leaf-shaped clay pieces with flattened top and bottom & horizontal \\
Laminae & spacer strips exhibiting vessel impressions from multiple & horizontal \\
Interstack abutment & stacks with multiple (often perpendicular) orientations & multiple \\
Miscellaneous & fragments and irregular pieces of fired clay & indeterminate \\
\hline
\end{tabular}




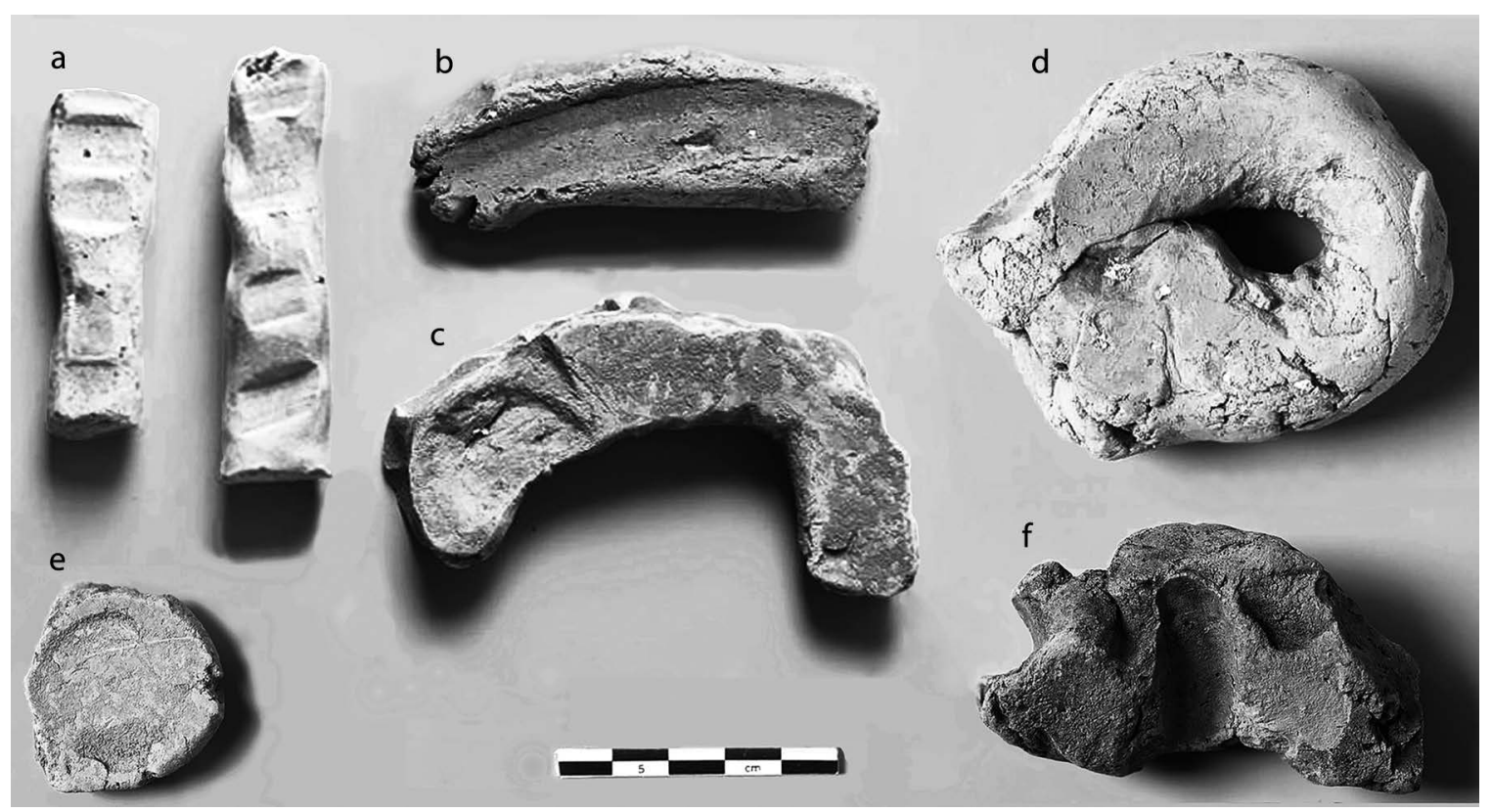

FIG. 3. Primary kiln furniture types: $a$, vertical spacer strip; $b$, horizontal spacer strip; $c$, wedge; $d$, coil; $e$, disk; $f$, interstack abutment (courtesy Sagalassos Archaeological Research Project).

ones. This may be related to the thinness of the walls preferred in the earlier period. The possible threat of vessel damage posed by large inclusions (e.g., being "dragged out" when the vessel is later turned, creating surface cracks during firing) seems to have been recognized by the second-century potters, as multiple examples of repairs for this problem were identified, particularly among the jug and jar fragments in the data set for the Early Roman period. These repairs appear as irregular surfaces where a particle or possibly an air bubble was punched through the vessel wall with a point tool and subsequently plugged with clay and smoothed over to "hide" the wall damage (fig. 5). That the vessel was still somewhat wet when repaired is evident by the irregular appearance on the exterior wall face where the plug of clay was smoothed over. As this interior damage appears only on closed vessels, it would not have been noticeable to the buyer, and it was therefore left unfinished. Although examples of inclusions were also observed in the Late Antique material, they were infrequent, and this repair technique was observed in only a single instance.

The risk posed by inclusions in the clay body thus seems to have been recognized by the potters during the Roman period, and this may help explain the increased levels of investment in clay-preparation facilities found in workshops dated to that period. It has

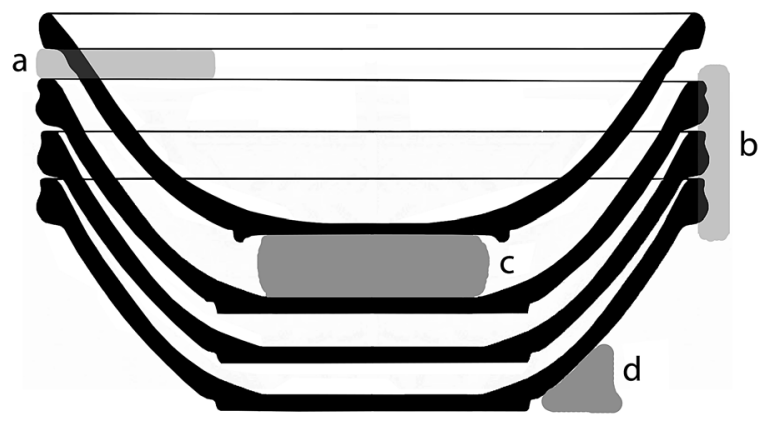

FIG. 4. Reconstruction of the main types of kiln furniture and their placement in vessel stacking: $a$, horizontal spacer strip; $b$, vertical spacer strip; $c$, coil; $d$, wedge.

been proposed, in fact, that the purposeful selection of clay in the Augustan period from the Çanaklı Valley, located some distance from Sagalassos, may have been motivated by an interest in its naturally "cleaner" quality, in comparison with clays found in the immediate vicinity of the Eastern Suburbium. ${ }^{35}$ As concerns the refinement of fabric clay, there is no clear evidence in any workshop at Sagalassos for the practice of levigation (i.e., clay being fully suspended in water tanks),

\footnotetext{
${ }^{35}$ Poblome 1995, 503.
} 
TABLE 3. Overview of technical shifts in Sagalassos Red Slip Ware production.

\begin{tabular}{|c|c|c|}
\hline & Mid First to Mid Second Century C.E. & Late Fifth to Early Sixth Century C.E. \\
\hline \multirow[t]{4}{*}{ Deposit information } & 3,642 diagnostic sherds analyzed & 3,475 diagnostic sherds analyzed \\
\hline & 12 SRSW forms & 15 SRSW forms \\
\hline & 148 pieces of kiln furniture & 318 pieces of kiln furniture \\
\hline & $6 \%$ of assemblage misfired & $11 \%$ of assemblage misfired \\
\hline \multirow[t]{3}{*}{ Vessel characteristics } & mostly $<25 \mathrm{~cm}$ diameter & mostly $<35 \mathrm{~cm}$ diameter \\
\hline & $\begin{array}{l}74 \% \text { bright orange-red surface } \\
\text { coloration }\end{array}$ & $\begin{array}{l}68 \% \text { dark purplish-red to brownish-red } \\
\text { surface coloration }\end{array}$ \\
\hline & more consistent coloration & $\begin{array}{l}\text { less consistent coloration ( } 10 \% \\
\text { displaying different coloration on interior } \\
\text { vs. exterior or rim vs. body of vessel) }\end{array}$ \\
\hline Clay preparation & removed inclusions & - \\
\hline \multirow[t]{4}{*}{ Vessel forming } & $\begin{array}{l}\text { overturning/overtrimming of vessel } \\
\text { bases }\end{array}$ & heavier walls and bases \\
\hline & $\begin{array}{l}\text { appliqué relief on wheel-thrown } \\
\text { wares }\end{array}$ & molded relief wares \\
\hline & hand-carved molds & stamp-decorated molds \\
\hline & $\begin{array}{l}\text { stamp impressions on exterior of } \\
\text { wheel-thrown wares using guidelines }\end{array}$ & $\begin{array}{l}\text { stamp decoration on interior of wheel- } \\
\text { thrown wares }\end{array}$ \\
\hline \multirow[t]{2}{*}{ Slipping } & thinner application of slip & thicker layer of slip \\
\hline & $\begin{array}{l}\text { incomplete "double-dip" leaving } \\
\text { middle of vessel without slip }\end{array}$ & - \\
\hline Drying & $\begin{array}{l}\text { few stacking marks (pre- or } \\
\text { postslipping) }\end{array}$ & $\begin{array}{l}\text { light scratching from being stacked before } \\
\text { firing }\end{array}$ \\
\hline \multirow[t]{3}{*}{ Kiln stacking } & open stacking of kilns & use of container forms in kiln stacking \\
\hline & $\begin{array}{l}\text { more horizontal kiln furniture } \\
\text { (wedges, coils, horizontal strips) }\end{array}$ & more vertical spacer strips \\
\hline & - & $\begin{array}{l}\text { vertically incised lines on the rim ("batch } \\
\text { markers") }\end{array}$ \\
\hline
\end{tabular}

SRSW = Sagalassos Red Slip Ware

yet in a Roman period (first- through third-century C.E.) workshop a series of "weathering" pits (i.e., pits in which the clay is exposed to the elements to yield a more plastic fabric), as well as an adjoining room with a plastered floor, were found.

In the later period, the Çanaklı clays continued to be exploited. Yet in contrast to spaces dedicated to clay processing found in the Roman-period workshop, the infrastructure for clay processing in a Late Antique (early sixth-century) workshop that specialized in moldmade wares was more modest in size. Here, a thick deposit (ca. $20 \mathrm{~cm}$ ) of prepared Çanaklı clay was found piled on the floor along the edge of a single room. Embedded in the clay deposit was a ceramic container form (likely for water) inside of which was a long scraper fashioned from a cow rib. This arrangement of clay and 


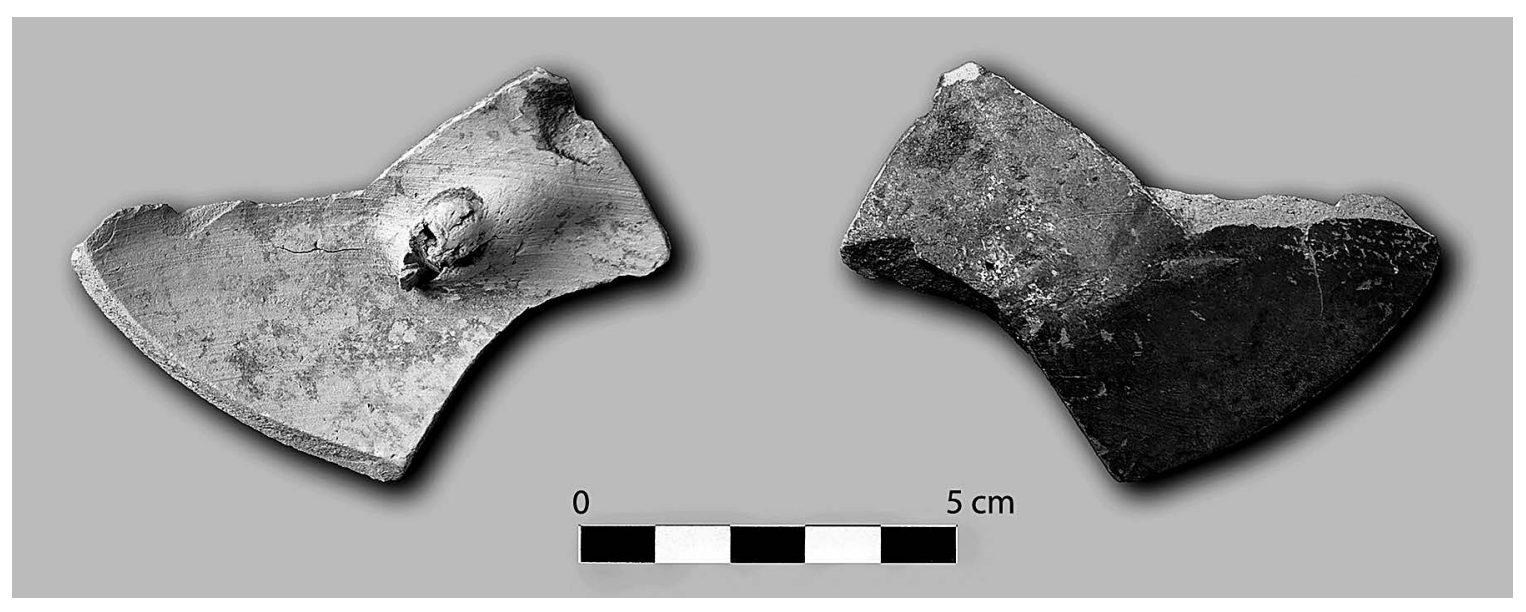

FIG. 5. Example of a second-century C.E. repair technique to remove a large inclusion or air bubble from the wall of a jug: left, interior wall; right, exterior wall. The wall has been pierced, then plugged with clay. Note the flattened outer face where the clay was smoothed over to hide the repair (courtesy Sagalassos Archaeological Research Project).

associated artifacts is consistent with ethnographic descriptions of potters preparing the clay by "treading" it with their feet. ${ }^{36}$ Thus, the clay employed in both periods appears to have been prepared, yet with different degrees of investment in the necessary infrastructure.

Forming. The predominant forming technique used on the vessels of either period was wheel throwing with secondary trimming or turning. Excavations of workshops have also produced evidence of pottery wheels from the later phases of production at the site. The predominant type of the sixth century C.E. appears to have used a cylindrical limestone drum base (diam. ca. $30-40 \mathrm{~cm}$; ht. ca. $70 \mathrm{~cm}$ ) on top of which a wheel would have turned. ${ }^{37} \mathrm{~A}$ depression (diam. ca. $10 \mathrm{~cm}$ ) was carved into the upper face of these drums; this depression has been interpreted as a stationary receptacle in which the wheel head spun. There is currently no direct evidence for the wheel heads themselves; however, these stone supports have been found in nearly every Late Antique ceramic workshop in the industrial quarter, often accompanied by a low, flat rock (which presumably served as a seat)..$^{38}$

Vessels of the Roman period typically demonstrate a greater time investment in secondary turning at the

\footnotetext{
${ }^{36}$ For ethnographic examples of this technique, see Rye and Evans 1976, 21, 90-1, 214, 271; Crane 1988, 11-12.

${ }^{37}$ There is some evidence for other wheel types with smaller metal axles and possibly wooden wheel heads, but it is far less common than the evidence for the type described above. For descriptions, see Murphy and Poblome 2013.

${ }^{38}$ Murphy and Poblome 2013.
}

leather-hard stage of drying than those of the Late Roman period. Most of the vessels from this early period display trim marks running up their outer walls. In general, the Late Roman dumps show less extensive turning, with only the lower outer wall secondarily trimmed. This thorough turning in the Roman period appears to have posed a serious production risk, as numerous examples of bases that had been cut too thin and either punctured or broken during firing are evident in the early dump material (fig. 6a, b). ${ }^{39}$ This production flaw has been identified on a wide range of forms (e.g., bowls, dishes, plates) and seems to be a problem related to the general techniques employed during the period to achieve a sharp vessel contour and thin walls and bases. Occasionally, repair techniques were attempted. This required a second disk of the same diameter to be cut and applied across the exterior of the thinned base to reinforce the bottom (see fig. $6 c, d$ ). Yet this clay addition was not always successfully fixed when fired, as multiple examples in which the secondary bases became detached are present in the dumps. That this repair technique was also known in the Late Roman period is evidenced by a single example observed in the contemporary dump material; however, in general, examples of thinly cut bases are infrequent in the later material, likely because of the heavier walls and bases common at that time. In general, the Late Antique material has few recurrent

\footnotetext{
${ }^{39}$ Bases are much more difficult to associate with specific typological forms.
} 


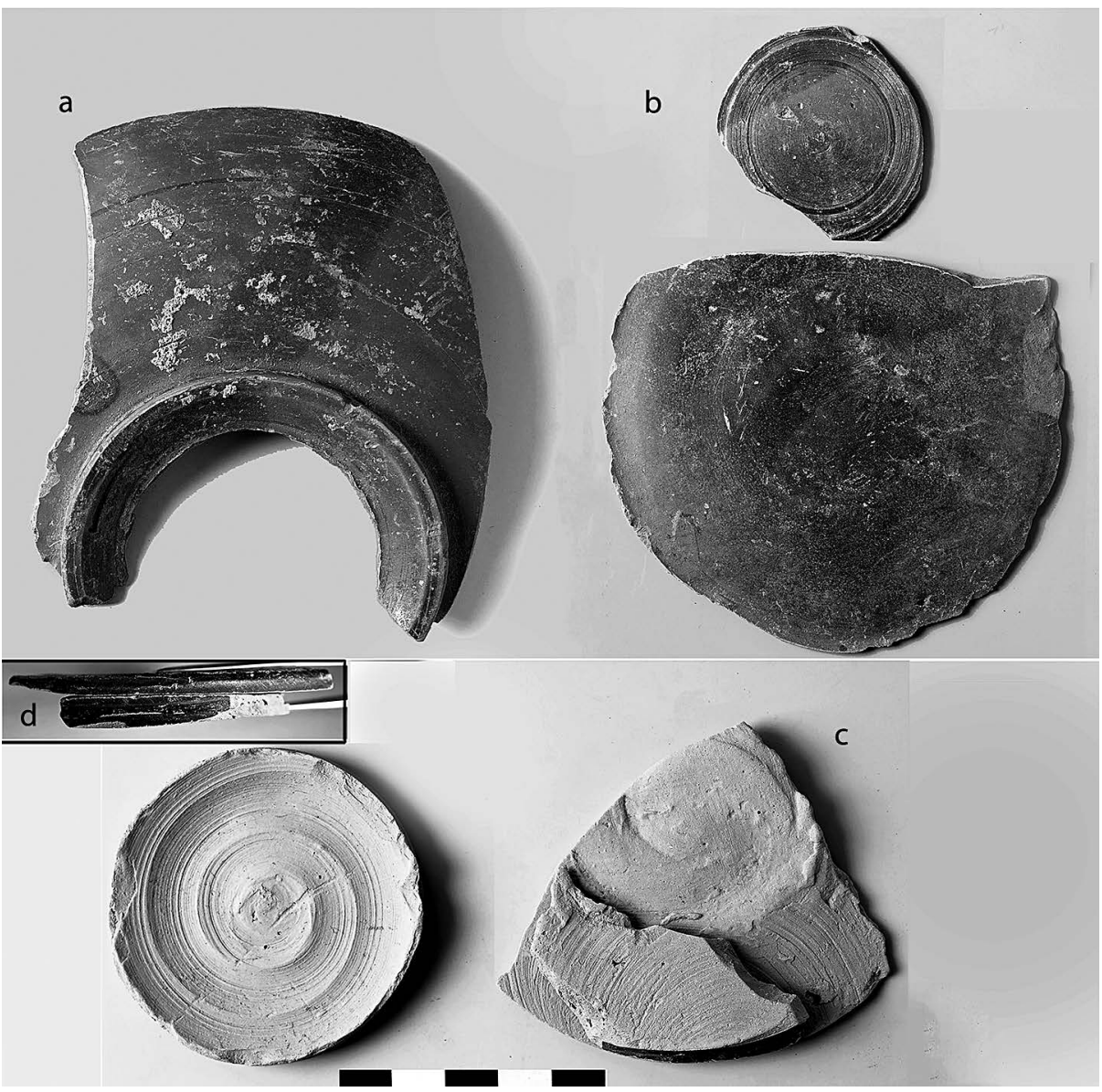

FIG. 6. Examples of tableware wasters with thinly cut bases: $a, b$, broken bases; $c$, two base appliqués (an attempted repair technique to reinforce bases that were originally cut too thin) that "popped off" during firing; $d$, profile view of an attached disk, as it had once been positioned on the base of a vessel. Scale bar is $5 \mathrm{~cm}$ (courtesy Sagalassos Archaeological Research Project).

problems in the forming stage; occasionally an irregular rim or base is observable, but rarely do such issues affect the structural integrity of the vessel.

In both deposits, a modest number of molded relief wares is also present. In the early deposits, the relief decoration occurs on a variety of vessel forms, but mostly as appliqué on the exterior walls of tall bowls (fig. 7). Both hand-formed and molded appliqué parts were used, often in combination. The hand-formed appliqués tend to be simple decorative elements (e.g., vines, geometric motifs) rendered through the application of small pellets or thin coils. The molded appliqués are typically very detailed and often figural. This method of attachment was technically rather difficult, as little to no pressure could be exerted onto the decorative face of the appliqué without disturbing the image, and several examples where the appliqué became detached are present in the dump material. Appliqué relief wares are certainly not unique to Sagalassos and are known from some of the major tableware production centers of the Roman world, such as at Gaulish production centers, where appliqués were used to decorate closed forms (i.e., jugs and jars), ${ }^{40}$ and at third-century North African production sites, where appliqués decorated mostly open forms. ${ }^{41}$ Closer to Sagalassos, in Asia Minor there was also a tradition of appliqué relief decoration during the Hellenistic and Early Roman periods at Pergamon, Ephesos, and Knidos. ${ }^{42}$

${ }^{40}$ Mees 1995.

${ }^{41}$ Hermann and van den Hoek 2002, 6-7.

${ }^{42}$ Pergamon: Hübner 1993; Japp 2014. Ephesos: Rogl 2003. Knidos: Kögler 2014, 164-65. 


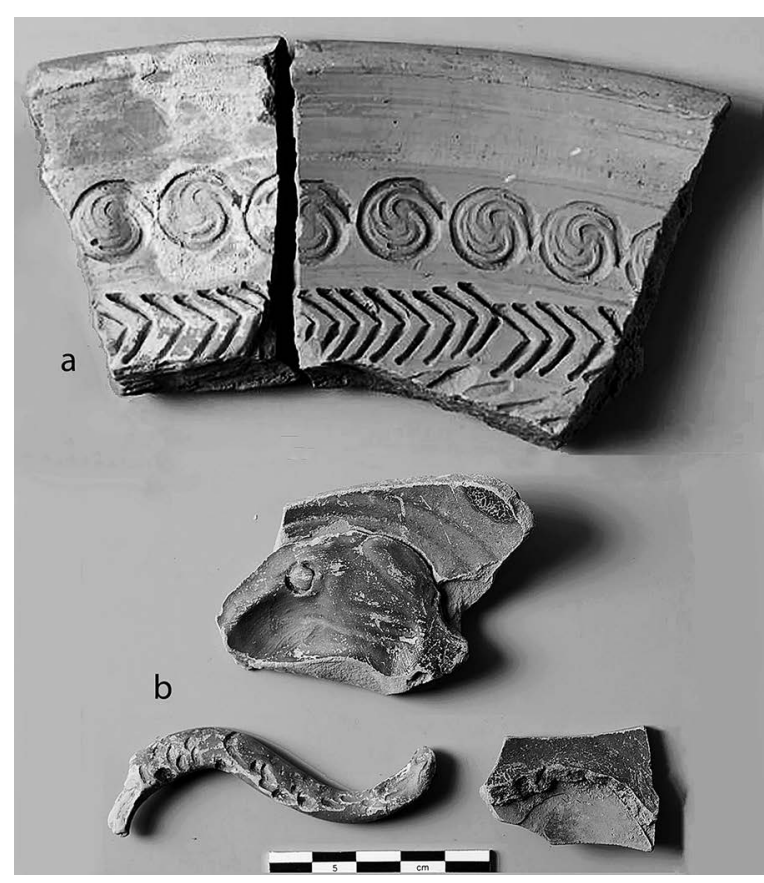

FIG. 7. Examples demonstrating different relief decoration techniques: $a$, mold with stamp impressions, Late Antique period; $b$, appliqué relief, Roman Imperial period (courtesy Sagalassos Archaeological Research Project).

Other early uses of relief decoration at Sagalassos include the use of hand-carved molds for the production of ledge handles, which were attached to wheel-thrown bowls and dishes. ${ }^{43}$ Molds are used more regularly in the late fifth to early sixth century, mostly as two-part molds for oinophoroi and occasionally as single molds for cups and bowls. The technique used in this later period is quite different from earlier appliqué techniques. Here, the investment is placed in the production of a wide range of stamp designs. Each stamp (figural or geometric) is hand carved from clay (the same as that used for the body clay of Sagalassos Red Slip Ware) and impressed into blank molds (see fig. 7a). Used in combination, the stamps offered greater flexibility for creating decorative scenes and borders than the techniques used in the earlier period. Moreover, when the amount of labor invested in the process of hand carving the stamp is compared with that needed to hand carve each mold individually, time and coroplastic skill sets seem to have been allocated in more versatile, and perhaps even more time-efficient, ways in the later period.

${ }^{43}$ Poblome 1997.
These types of stamped molds are consistent with the types associated with tableware production centers from the Late Hellenistic through the High Imperial periods. The molds found in first- to third-century C.E. Italian and Gaulish centers typically display a small hole by which they were attached to the pottery wheel in an arrangement typically referred to as a "jolly" by modern potters. ${ }^{44}$ In this configuration, the vessel is thrown inside of the mold. Examples of molded wares that are finished on the potter's wheel are also documented in the eastern Mediterranean during the Late Hellenistic and Early Imperial periods. For example, molds for hemispherical bowls locally produced at Sardis and Athens were also decorated using a combination of stamped and hand-carved motifs. ${ }^{45}$ Yet these molds lack a central hole where they could be attached to the wheel head. As Rotroff and Oliver have noted, however, such molds typically have their own bases on the exterior. ${ }^{46}$ These bases would have ensured that the mold was perfectly upright on the wheel head and would have offered a ledge against which wet clay pads could be pressed to prevent horizontal shifts as the wheel rotated. In this tradition of eastern Mediterranean hemispherical cups and bowls, there is little evidence for the use of a formal jolly arrangement, and, in fact, the placement of the attachment hole would have interrupted the decorative design of the hemispherical bowl being molded.

As of yet, we have no evidence for jolly-style arrangements in any of the Sagalassos material, nor do we have evidence for the local production of the Late Hellenistic and Early Roman molded hemispherical bowls. By the sixth century, from which time relief wares at Sagalassos are more common in the archaeological record, relief-decorated vessels were primarily closed forms manufactured in two-part molds, in which the clay was pressed into the mold by hand (as evidenced by the orientation of tool and finger marks) and wheel-thrown necks were subsequently attached to the molded body. Most of the occasional relief-decorated cups in the sixth century were also hand-pressed into the mold.

Stamped wares occur in open forms in both periods of production at Sagalassos. In the second-century material, stamping most commonly appears on the exterior walls of small cups. Guidelines were first lightly incised into the outer wall while the vessel turned on the wheel, and stamps were then impressed along that

\footnotetext{
${ }^{44}$ Mees 1995; Hayes 1997, 8.

${ }^{45}$ Sardis: Rotroff and Oliver 2003. Athens: Rotroff 1982.

${ }^{46}$ Rotroff and Oliver 2003, 96.
} 
line to maintain an even overall decoration. These stamps tend to be relatively simple in shape (e.g., lozenges, circles). Stamp impressions on Sagalassos Red Slip Ware became increasingly prominent in the fourth to sixth century C.E. With the larger open forms popular at that time, decorative emphasis moved from the outer wall of small cups and bowls to the inner base, appearing as central decorative motifs on large platters. ${ }^{47}$ Similar platter forms are well known from North African production centers, where the transition from relief appliqué decoration to stamped decoration on open forms appears to have taken place in the third century C.E. ${ }^{48}$

In general, at Sagalassos, significant technical variation can be detected in vessel forming, both within and between the two data sets. It is clear, however, that while the forming techniques (and repairs) are part of a larger tradition maintained from the Roman to the Late Antique periods, these techniques occurred in different frequencies in each. For instance, the use of an appliqué disk to thicken a vessel's base more often occurred in the earlier production of small, heavily turned forms. Not surprisingly, these changing frequencies are again associated with evolving Sagalassos Red Slip Ware forms, with trends in the shape, size, and wall thickness of those forms for each period resulting in a consistent use of certain techniques to address recurring production challenges. In other cases, the technical emphasis appears to have been placed on different segments of the production process rather than on different skill sets. This was the case with the Late Roman repertoire, which emphasized a greater investment in the production of stamps (as opposed to molds). Yet, as regards such decorated relief ware, while the techniques employed at Sagalassos are all known to have been used at other sites in the Roman world, the combination, sequence, and duration of their use seem to be fairly unique to the manufacturing tradition practiced at Sagalassos.

Kiln Stacking and Firing. Most evidence from the waste material concerns kiln firing. This is unsurprising since, if problems or defects had been identified in earlier stages of production, the unfired vessel's clay could have been recovered through soaking. Interestingly, although the general design and dimensions of ceramic kilns remained largely the same throughout

\footnotetext{
${ }^{47}$ This shift in design layout is noted in Swift 2007, 387; 2009, 107-23.

${ }^{48}$ Mackensen 1993; Hermann and van den Hoek 2002, 6.
}

both periods, the kiln-stacking procedures were remarkably dissimilar. As is demonstrated in the following discussion, these changing stacking techniques had major implications for the technological choices made during each period.

In each period, regularly occurring types of kiln furniture are unmistakable and repeated so frequently that it becomes clear both that they were used in somewhat standardized ways and that certain kiln-loading protocols were followed. Overfired sherds that became partially or fully fused to other (touching) vessels demonstrate that open forms (the predominant forms in the deposits) of the same type and size were often placed in stacks within the kiln. Vessels overfired until fully vitrified also display heat exposure at the lower wall or base and downward-melted drippings or slumping consistent with an upright orientation in the kiln. During the earlier period of production, however, vessels seem to have been simply stacked in the firing chamber using only kiln spacers, especially spacer strips. Open forms appear to have been set among the stacks with no evidence for temporary shelving. This direct-load method of kiln stacking during the Roman Imperial period contrasts with practices followed in the later period, when large, straight-walled containers were used to hold stacks of vessels. In some cases, the large Sagalassos Red Slip Ware lekanai (primarily Type 1F140, but also $1 \mathrm{~F} 160,1 \mathrm{~F} 170$, and $1 \mathrm{~F} 180$ ) were used, while in other cases large containers in a coarse fabric (Types 2F100, 2F110, and 2F120) were employedparticularly at the lower levels of the kiln load, where localized overfiring appears to have occurred from heat exposure at the perforations of the kiln floor. ${ }^{49}$ Examples of tableware stacks fused to the interior of these vessels and discoloration rings on the inner base (where the base of another vessel was positioned) suggest that these containers were employed as makeshift saggers for the kiln.

These coarse ware containers were also likely manufactured in the workshops and exhibit straight sides transitioning from a rounded lower wall to a very thick, flat base (fig. 8). ${ }^{50}$ In some cases, their rims follow the

\footnotetext{
${ }^{49}$ For descriptions of these types, see Degeest 2000, 137-38, 361-62, figs. 126-29.

${ }^{50}$ Several kiln spacers in Fabric 2 were found in the dump material, confirming that raw Fabric 2 clay was present in the workshops. Therefore, both the materials and means of producing the containers were entirely available within the workshop, and there is no reason to assume they were acquired from elsewhere.
} 


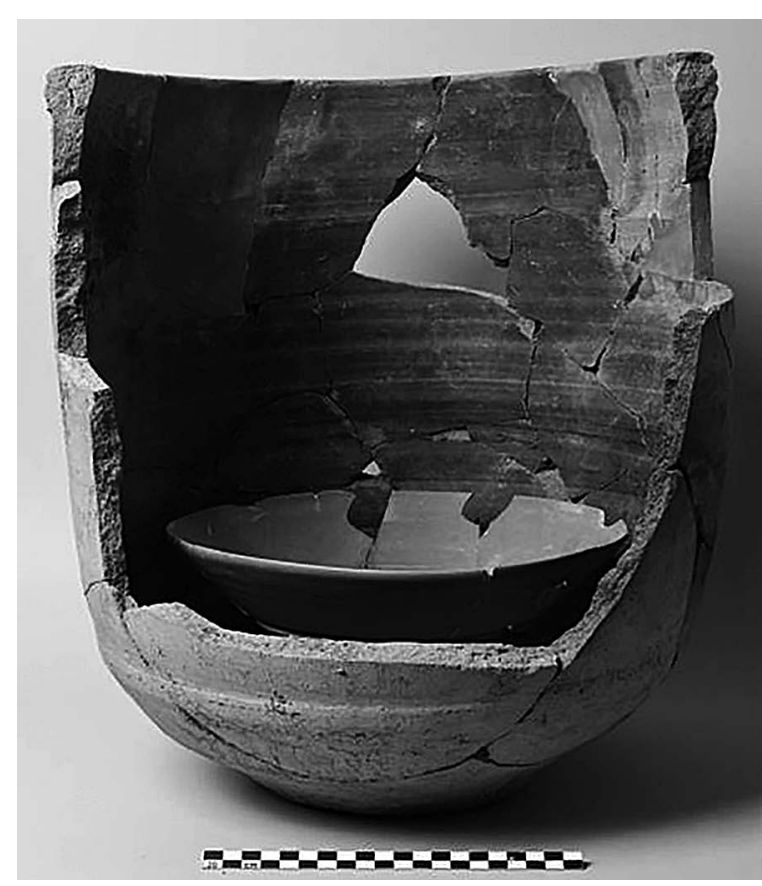

FIG. 8. Reconstruction of a sixth-century C.E. Fabric 2 container with Sagalassos Red Slip Ware bowl inside (courtesy Sagalassos Archaeological Research Project).

same morphologies as the Sagalassos Red Slip Ware Fabric 1 lekane series. Importantly, the coarse ware containers infrequently appear in contemporary urban consumption contexts, and their spatial distribution is overwhelmingly in industrial craft-production contexts and areas, especially in the Eastern Suburbium and its workshops. This suggests that these forms may have been produced predominantly for industrial purposes. Their first appearance seems to have been in the first quarter to middle of the fourth century C.E., ${ }^{51}$ but they did not become widespread in production-related deposits until the early fifth century. ${ }^{52}$ The typological genealogy of the container series seems to be embedded in a local tradition that can be traced from the Hellenistic period to the Type 1F150 lekane of the Imperial period, and to the fourth-century Type 1 F160,

\footnotetext{
${ }^{51}$ Two examples (one Type 2F100 and one Type 2F110) were found in the secondary production waste deposit (Layer 3 ) in the Neon Library. Degeest (2000, 200-6) dated the deposit to the third quarter of the fourth century C.E. For the redating, see Poblome et al. 2008.

${ }^{52}$ Examples were also found in the early fifth-century C.E. production waste deposit from the Eastern Suburbium (SA-1998-PQ-37).
}

1F170, and 1F140 lekane forms. Displaying different rim and wall morphologies through time, the $1 \mathrm{~F}$ series also becomes larger. The coarse ware $2 \mathrm{~F}$-series containers are related to these later phases of the fine ware types, and, although not exclusively designed as saggers, they were clearly adopted for that function within the workshops.

The change in stacking strategy associated with these container types is also evidenced through kiln spacers. While neither the typology of kiln spacers nor the size and number of vessel impressions changes substantially between the periods, ${ }^{53}$ kiln spacers in the earlier period do nonetheless show different relative proportions of the total assemblage: There was an earlier preference for spacers that would support the vessels from horizontal shifts and a later emphasis on vertical cinching (fig. 9). That is, the most common type of kiln furniture in the earlier material is the clay wedge, while the vertical spacer strips are most common in the sixth century. As potters in the later periods used larger containers as makeshift saggers, there appears to have been less concern for horizontal movements in the kiln, which would be stopped by the larger vessel's walls. In order to better assess this transition in kiln-stacking techniques, an additional deposit dated to the early fifth century C.E. was then analyzed. The composition of spacers from that deposit suggests that this technological transition in firing techniques at the site occurred somewhat gradually through time, as the ratio of horizontally vs. vertically oriented furniture types fell between the distributions of the second- and sixth-century deposits (see fig. 9).

These changes to the kiln-stacking methods in the later period are significant, in that they seem to correlate to certain features characteristic of the Late Roman repertoire. For instance, the surface slip in the later periods is more often "dark" in color (reddish purple to brown) than that of earlier periods. This may be due to the Sagalassos Red Slip Ware vessels being partially starved of oxygen while trapped within the larger containers during firing. These changes likely also had implications for other factors that are more difficult to assess archaeologically — for example, the vessel misfiring rates, the number of vessels that could be stacked in a single kiln load, and the extent to which Sagalassos

\footnotetext{
${ }^{53}$ E.g., the average length of spacer strips was $6.03 \mathrm{~cm}$ and $7.65 \mathrm{~cm}$, and the average number of impressions was 2.40 and 2.95 in the early and late deposits, respectively.
} 


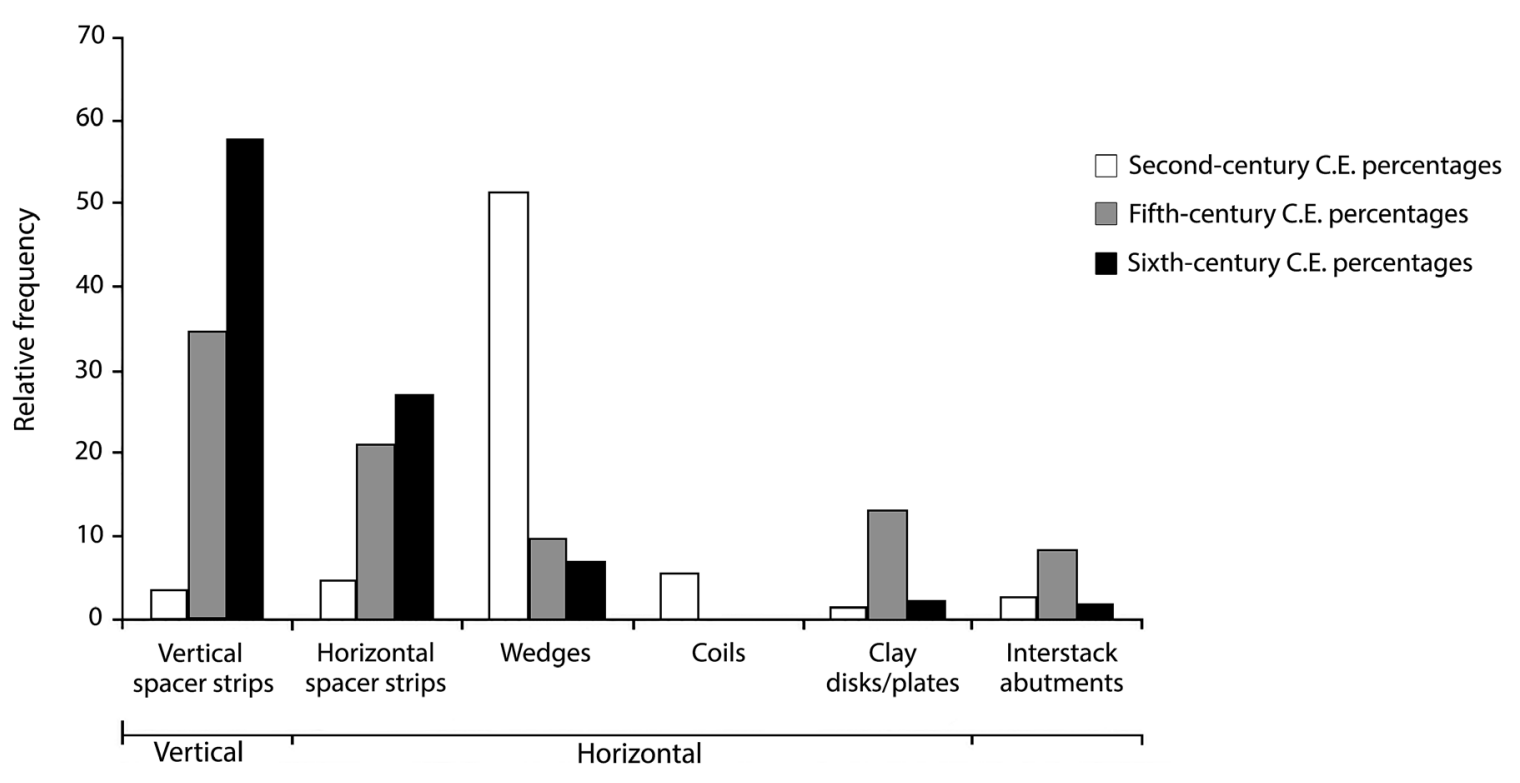

FIG. 9. Relative frequencies of different types of kiln furniture represented in deposits dated to different periods.

Red Slip Ware could be preloaded as batches into the larger container vessels.

Saggers, or "cassettes," used in ceramic red-slipped tableware production in the Roman world are most commonly associated with large-scale African Red Slip production sites. ${ }^{54}$ The North African examples, however, seem to be highly specialized for use as saggers, and with openings at both the top and bottom, they would not be useful in many other contexts. ${ }^{55}$ The Sagalassos examples seem to be largely industrial in function, yet (in contrast to the North African cassettes) were not exclusively employed for kiln firing, as examples have been found in the context of abandoned workshops serving as water receptacles and storage containers. Moreover, African Red Slip is believed to have been fired exclusively within the cassettes. ${ }^{56}$ In contrast, at Sagalassos both coarse ware containers and Sagalassos Red Slip Ware lekanai were used to hold stacks of Sagalassos Red Slip Ware bowl and dish forms. Therefore, as the Sagalassos production appears to use these containers in far less specialized and standardized ways, no direct technological connection can be assumed between the two industries. Instead,

\footnotetext{
${ }^{54}$ Peacock et al. 1990, 68; Mackensen 1993, 88; Bonifay 2004; Ben Moussa 2007, 188-90.

${ }^{55}$ Bonifay 2004, 60-5.

${ }^{56}$ Supra n. 54.
}

their contemporaneity may perhaps be an indication of more general technological trends taking place in Late Antique tableware production that simply have yet to be identified elsewhere.

The reason why such changes were made to the stacking procedure at Sagalassos is difficult to establish with any certainty, and in all likelihood the motivation was multifaceted. Using the evidence at our disposal we can, however, productively speculate. One notable observation is that the product repertoire seems to have been conceived within a sort of production system in which changes to one part of the product line influenced manufacturing decisions for other vessel types. This is particularly salient in the context of firing the kiln, as this is typically considered one of the most expensive procedures of the entire ceramic production process. ${ }^{57}$ More specifically, the popularity of larger vessels with thicker walls so common in the later period likely necessitated a hotter and/or longer heating of the kiln to completely fire the vessels, consequently exposing the vessels to more sustained heat and therefore increasing the risk of overfiring. This may have encouraged the use (and therefore the production) of larger containers, in some cases of a coarse fabric, to protect the more vulnerable bowls and plates. Within

\footnotetext{
${ }^{57}$ Rice 1987, 162-63.
} 
this system, the popularity of one type may have influenced not only the manufacturing technique but also the size and shape of other vessel types. There is, in fact, indirect evidence for this in the Late Antique diameter measurements; the interior diameters of the Sagalassos Red Slip Ware lekane forms, which fall between 14 and $35 \mathrm{~cm}$ (with most between 18 and 30 $\mathrm{cm})$, overlap and extend the diameter range of the Fabric 2 containers, which measure between 22 and $43 \mathrm{~cm}$ (with most between 28 and $42 \mathrm{~cm}$ ). Together, the distribution of the containers' interior diameters closely parallels the distribution of the exterior diameters for all the other forms that would have been stacked within them (fig. 10). ${ }^{58}$ Thus, the containers and the Sagalassos Red Slip Ware seem to have been made to specific diameters so that the various vessels fit together in the kiln.

Another possible explanation may relate to changes made to the firing process, such as the type of fuel being burned. Controlled refiring experiments have identified an optimal firing temperature for Sagalassos Red Slip Ware between 850 and $950^{\circ} \mathrm{C},{ }^{59}$ a range easily maintained in the type of simple updraft kiln found at Sagalassos (see fig. 1). ${ }^{60}$ Fuel samples taken from pottery kilns at other Roman-period production sites demonstrate that a wide range of materials could be used as fuel in such a kiln. For instance, at Leptiminus, Oudhna, Pergamon, and Athens, ${ }^{61}$ olive pits and pressing waste have been found, while at Dakhleh Oasis brushwood and straw have been observed. ${ }^{62}$ While we currently lack charcoal samples from industrial furnaces at Sagalassos because of poor preservation and postceramic furnace reuse, in the rest of the city charcoal identified from consumption deposits generally belongs to the same taxa from the Roman to Late Roman period, primarily cedar, oak, and pine. ${ }^{63}$ Recent palynological results ${ }^{64}$ however, suggest that changes in the agricultural regime of the region around Sagalassos were taking place by the fourth century C.E. and that most of the slopes in the territory would have been

\footnotetext{
${ }^{58}$ The containers would need to be slightly larger to accommodate the stacks with attached spacer strips.

${ }^{59}$ Poblome 1995, 503-4.

${ }^{60}$ Rice 1987, 160.

${ }^{61}$ Leptiminus: Stone et al. 1998, 313. Oudhna: Barraud et al. 1998, 144-45. Pergamon: Erdemgil and Ozenir 1982. Athens: Lygouri-Tolia 2000, 210.

${ }^{62}$ Hope 1978, 199.

${ }^{63}$ Elena Marinova Wolff, pers. comm. 2016.

${ }^{64}$ Vermoere et al. 2003.
}

eroded. This may hint at wider changes in landscape use affecting woodlands and potentially fuel supplies to the city's industry. Certainly, soft, resinous woods, such as pine, would create a high and fast-burning flame, as might brushwood or clippings, and shifts to such fuel sources might have motivated the adoption of ceramic containers to protect the tablewares; yet, based on the current evidence, such associations remain preliminary.

\section{Interpretation: Social Trends and Production Skill}

These observations offer several points for discussion concerning the characterization of Late Antique tablewares. For instance, although differences clearly emerge between the periods, as demonstrated by the above comparison of production techniques, these distinctions were not necessarily based on the level of skill of the artisans. In fact, difficulties and problems in producing ceramics are discernible in all periods of production at the site. What is interesting, rather, is the fact that the types of challenges faced by artisans changed through time, and those challenges can often be directly related to the particularities of the forms being manufactured. Specifically, this seems to concern increasing wall thickness and overall size, central characteristics associated with later tableware styles. Accordingly, care was undeniably still being given to the production process in the later periods, yet emphasis seems to have been placed on different aspects of manufacturing, with fewer time-intensive techniques employed in the forming and trimming stages and more expensive techniques and technologies employed in the firing stage. Thus, it is evident that products in both periods at Sagalassos display important differences in their overall appearance and execution while still evincing technical treatments consistent with the wider Sagalassos Red Slip Ware tradition. The design of the kilns, the types of raw materials, and the production of a red-slipped tableware were all maintained through the periods in question. What does appear to change, however, is the frequency of use of certain techniques, and only rarely are introductions of entirely new techniques observed. Therefore, rather than a dramatic disruption in the longer history of the production line, these changes are perhaps better described as "shifts" in the technical practice maintained within an established tradition or technological style. ${ }^{65}$

\footnotetext{
${ }^{65}$ Supra n. 9.
} 


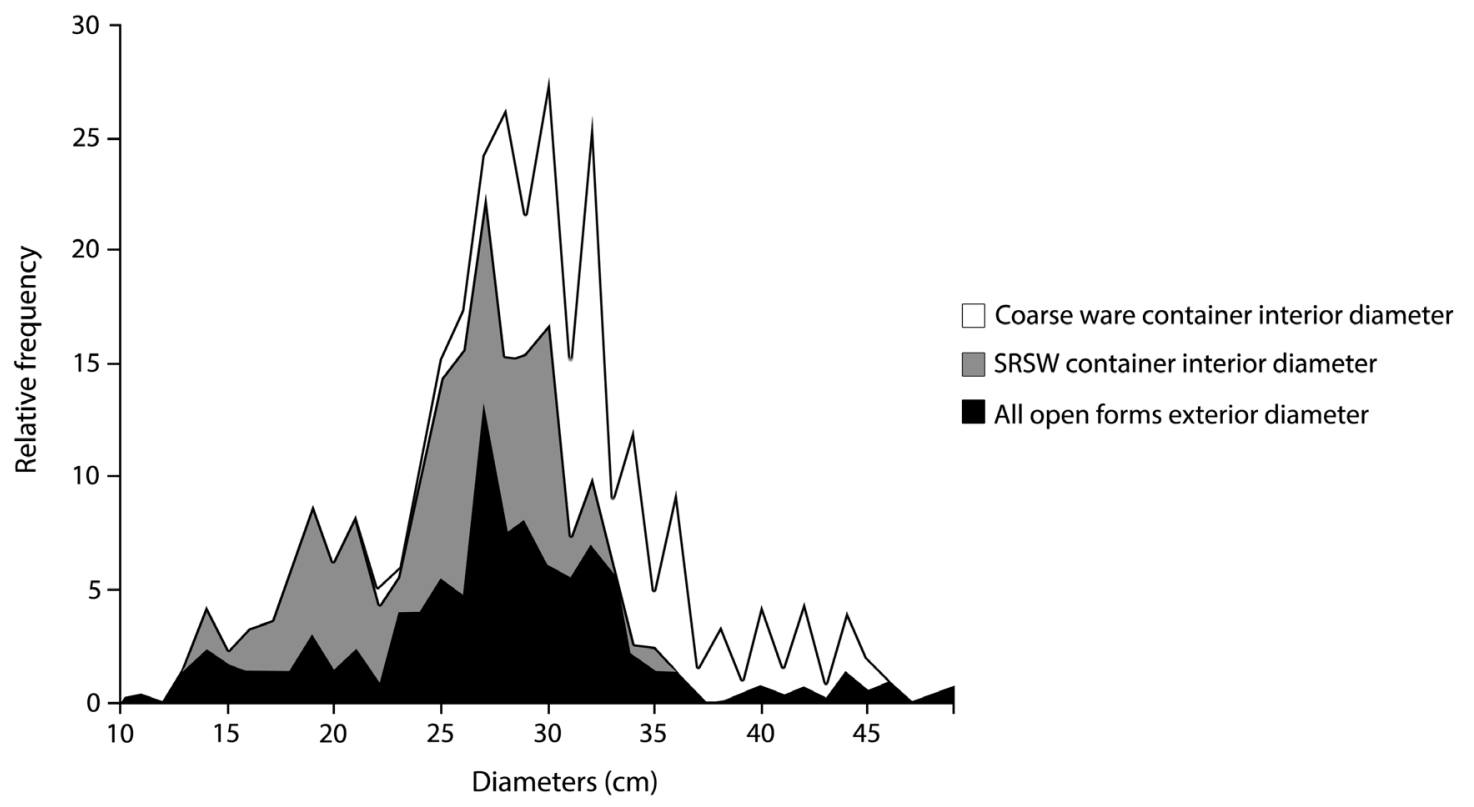

FIG. 10. Distribution of exterior rim diameters for Sagalassos Red Slip Ware in relation to the interior rim diameters of Sagalassos Red Slip Ware lekane containers and coarse ware (Fabric 2) containers from the sixth-century deposit (SRSW= Sagalassos Red Slip Ware).

If we compare how these shifts in technological evolution at Sagalassos relate to broader trends in the technological development of the period, it becomes apparent that they are consistent with techniques of red-slipped tableware production known from wellstudied, contemporary production centers elsewhere. For instance, the forming techniques described previously (i.e., decorating with appliqué, molding vessels in molds decorated with stamps, stamping large platters with central designs, extensively trimming complex profile shapes) are all well known from the period and can be observed at some of the largest red-slippedtableware production centers in Italy and Gaul during the High Imperial period or in North Africa during late antiquity. As already noted, the use of protective vessels in the firing of tablewares in simple updraft kilns is also documented at Late Antique African Red Slip production sites. ${ }^{66}$ To a certain extent, Sagalassos Red Slip Ware production was very much in keeping with ceramic production of the period. The selection and combination of those techniques, however, created a technological style decidedly specific to Sagalassos Red Slip Ware. Such a local (or potentially regional) phenomenon nonetheless holds relevance for the study of

\footnotetext{
${ }^{66}$ Supra n. 54.
}

Roman tablewares more widely, as it demonstrates the interplay between large-scale trends in ceramic technology and local expressions of technological practices.

\section{Physical Evidence for Production Organization}

It becomes clear that shifts in the typological repertoire of certain forms appear to have systematically affected the shape and size of other vessels. Consequently, it seems that technical changes in Sagalassos Red Slip Ware need to be considered in relation to the full repertoire of a given period, with each individual vessel type representing only a part of the total production system. Perhaps most clearly demonstrated in the example of kiln loading, the choice (and likely ratios) of the various types and their sizing seems to have been conceived in relation to the collective repertoire of the workshop. This demonstrates that explanations of consumer demand dictating stylistic changes in tableware should also take into account technical and economic decision making that occurred within the workshop and the influence of this decision making on the execution of ware styles. Furthermore, conceptualizing kiln loads as systems composed of related product types implies a degree of forethought concerning what types can fit together in a load and what size they should be, with possible implications for the overall organization of a workshop's production. 
Other patterns observed in the two data sets corroborate this sort of preplanning during both periods of production. This is most clearly demonstrated in the later deposit, with the recurrence of thin (average wdth. $1.43 \mathrm{~mm}$ ) incised lines on the exterior rim face of vessels, which suggests that vessel stacks may have been prepared in batches. These linear grooves most commonly occur alone or in pairs (in $45.5 \%$ and $51.4 \%$ of the cases from the deposit, respectively), and they rarely appear in sets of three or four. These lines were purposely incised using a point tool after partial drying and prior to slipping (fig. 11, left). Furthermore, fused stacks of overfired vessels found in other dump deposits display these same incised lines running down an entire stack of bowls (see fig. 11, right). Based on this evidence, the vessels appear to have been stacked together at various points in the production process, from the drying to the firing stages. The lines occur on a variety of bowl and plate forms ${ }^{67}$ with no association between the number of incised lines and vessel type. These incised lines seem to suggest that vessels of the same type were manufactured and marked as batches, and those batches were processed together through the production cycle. Yet interpreting what these batches represent is problematic, as they might relate to any number of factors in the organization of production (e.g., consignments, tracking of the output of a single potter or work group, vessel groups for kiln loads).

\section{PART 2: ECONOMIC IMPLICATIONS OF CHANGING STYLES}

The analyses in part 1 successfully identified several important technical shifts in the Sagalassos workshops over time, as related to the products popular in the two periods; one of the most visible shifts concerns the methods and means of stacking kilns-from freestacking vessels in the firing chamber to the use of larger, high-walled containers to support smaller stacks of bowls and plates. While these differing stacking methods are consistent with other technical changes likely related to the challenges of producing new types, we suggest that these changes would significantly affect the economics of making pottery. With kiln design and horizontal chamber size essentially unchanged throughout the two periods, the stacking of larger

\footnotetext{
${ }^{67}$ Sagalassos Red Slip Ware Types 1B130, 1B180, 1B200, 1B210, 1B220, 1B221, 1B230, 1B231, 1B232, 1B233, 1C161, and 1C180, 1C181 (Poblome 1999).
}

vessels of the Late Roman period clearly would result in fewer vessels being fired in a single kiln load. Put simply, larger vessels in the same-sized kiln results in fewer vessels per kiln load. While it is not possible in this article to take into account certain essential costs (e.g., raw materials, labor), these kiln-load estimates do suggest that at least some of the production costs accrued, particularly those associated with the expensive act of firing a kiln, ${ }^{68}$ may have been significantly higher per vessel in the Late Antique period. The following section considers whether, given the quality of this dump material and the present reconstruction of the firing process, it is possible to acquire a rough estimate of the changes in vessel counts per kiln load. This would allow us to assess how significant this effect might have been on the economics of workshop manufacturing through time.

Interest in quantifying economic activity in antiquity has attracted some attention among economic historians. ${ }^{69}$ Such quantified studies have likewise been applied to Roman ceramic distribution and consumption..$^{70}$ These studies have been fraught with complications and challenges resulting from the highly fragmentary and incompatible nature of evidence for the period. ${ }^{71}$ Attempts to quantify Roman ceramic production have likewise been performed at ceramic production sites, primarily through the estimation of kiln loads. Perhaps most notable are the kiln estimates for the "grand four" from La Graufesenque (southern France), which indicate tens of thousands of vessels per kiln firing, ${ }^{72}$ but estimates have also been made at other sites, such as Oudhna, Khirbet Baraqa, Brindisi, and La Boissière-École. ${ }^{73}$ Such reconstructions were performed to infer a site's overall scale of manufacturing output at a single point in its production history or to assess the dimensions and technical workings of the kiln. Other exercises, such as that performed for the site at Sallèles d'Aude (southern France) ${ }^{74}$ and the one performed here, intend to estimate more refined

\footnotetext{
${ }^{68}$ Supra n. 57.

${ }^{69}$ Bowman and Wilson 2009.

${ }^{70}$ Fentress and Perkins 1987; Fentress et al. 2004; Poblome 2004.

${ }^{71}$ Greene 1986, 9-14; Wilson 2009.

${ }^{72}$ Labrousse 1980, 467.

${ }^{73}$ Oudhna: Barraud et al. 1998. Khirbet Baraqa: Gadot and Tepper 2003, 148-49. Brindisi: Pallecchi 2012. La BoissièreÉcole: Dufaÿ et al. 1997, 88.

${ }^{74}$ Laubenheimer 2001.
} 


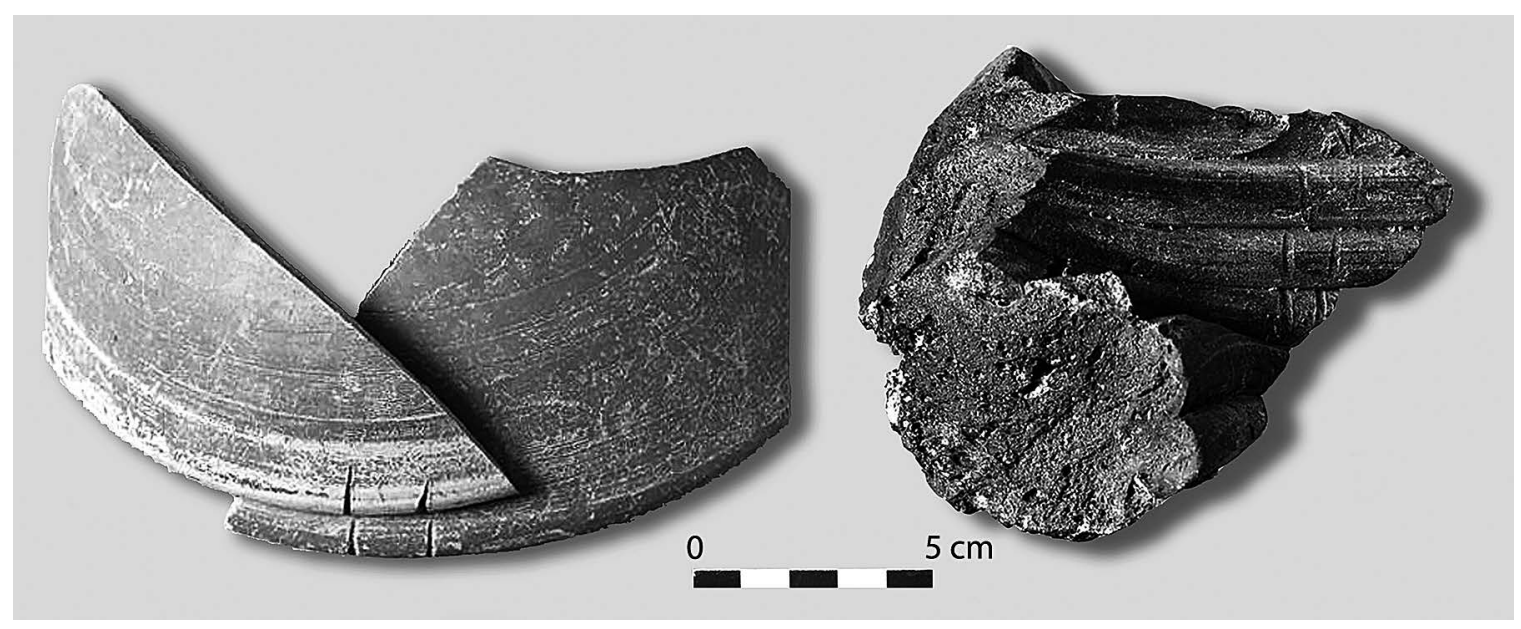

FIG. 11. Examples of tableware wasters with incised lines on rim: left, incised lines in the rims of Late Antique vessels; right, incised lines running down the rims of a fused (overfired) stack of bowls (courtesy Sagalassos Archaeological Research Project).

changes in the output of a single production center over time. Most of these quantifications, however, assert largely heuristic intentions and nonspecific results, and a similar aim is pursued through this exercise.

These quantification exercises have especially served as a means of ascertaining changes in the scale and performance of ancient pottery manufacturing, and changing pottery frequencies of major wares, such as African Red Slip, have been recovered through regional survey reflecting overall fluctuating production output and distribution through time. ${ }^{75}$ While the African Red Slip data did seem to follow changing volumes of production, the results of the quantification exercise here suggest that several other economic factors might also have been involved. In the case of Sagalassos, for instance, the smaller kiln loads appeared in the second half of the fourth century, a time in which the regional economy seems to have been generally expanding. ${ }^{76}$ Therefore, rather than representing a definitive sign of economic downturn or contracting demand, these smaller kiln outputs seem to represent a subtler interplay between internal technical choices made by the workshops and changing consumer tastes in pottery styles; that is, it is representative not simply of changing scale in consumer demand but also of the changing nature of that demand (and consequential producer responses to it). As is highlighted in the following dis-

\footnotetext{
${ }^{75}$ Fentress and Perkins 1987.

${ }^{76}$ Supra nn. 14, 17.
}

cussion, those workshop choices likely had profound implications for the production costs of pottery.

\section{Methodology}

There are two primary sets of variables involved in the reconstruction of kiln loads, and each is based on certain assumptions and presents unique sets of limitations. First, kiln dimensions (most importantly the interior dimensions of the firing chamber, which holds the vessels) must be determined to establish the spatial parameters into which the reconstruction must fit. Second, the contents of the kiln load must be assessed. This requires calculating the relative frequencies of the vessel types being loaded, the horizontal and vertical dimensions of those vessel types, and the methods of stacking each vessel type in the firing chamber.

Kiln Dimensions. Dozens of kilns in various states of preservation have been uncovered at Sagalassos. Proportionally, more date to the Late Roman period than to the earlier periods, but enough have been recovered to establish that they all follow the same (general) design: a vertical two-chambered, simple updraft type with a lower combustion chamber (where fuel is burned; see fig. 1c) and an upper firing chamber (where the vessels are stacked; see fig. 1a). The upper and lower chambers are separated by an elevated, perforated floor (see fig. 1b). There may be some variation in the type of pilaster or column support for the perforated floor; however, this is difficult to demonstrate as the floors are rarely preserved intact. The best-preserved floor has a central pilaster from which arches of building tile 
radiate and on which was constructed the floor of tile and mud plaster. Materials used to construct the kilns are likewise consistent, at least within the period under investigation. ${ }^{77}$ The outer support walls of limestone rubble and packed earth form a square or rectangular enclosure around the lower chamber walls and flue. The keyhole-shaped or round kiln plan is constructed in tile and brick, with a thick clay lining over the interior walls. In the firing chamber of our best-preserved kiln (and the only one preserving part of the firing chamber), large rectangular, terracotta bricks (lateres) were vertically affixed to the plastered wall.

There is also some variation in the size of firing chambers of the kilns from Sagalassos, with interior diameters ranging between 0.7 and $1.8 \mathrm{~m}$. The smaller diameters, however, are exclusively associated with the manufacture of small, molded-ware products. ${ }^{78}$ If these specialized small kilns are removed from the data set, there is no significant variation in the horizontal size of kilns between the two periods. Consequently, a diameter of $1.2 \mathrm{~m}$ (a typical diameter in all periods) was used to set the horizontal dimension. Establishing the height of the kiln firing chambers was among the greatest challenges to this series of measurements. The superstructures of the kilns at Sagalassos (as at nearly all ancient sites) have all been truncated by subsequent activity across the area, leaving no clear evidence for their original heights. Examination of various kiln fragments (both in situ and secondarily discarded) revealed no evidence for "beehive" roofing, and, in fact, a simple, temporary covering (e.g., tiles, large sherds) would have sufficed to produce Sagalassos Red Slip Ware. As it is impossible to establish with any certainty the original chamber heights of these kilns, the reconstruction was based on the standard sizing of the bricks that lined our best-preserved kiln chamber. Assuming that the firing chamber was two bricks tall in this kiln, ${ }^{79}$ this provided a chamber height of $0.97 \mathrm{~m}$.

\footnotetext{
${ }^{77}$ Before the second-century C.E. introduction of fired brick for building at Sagalassos, the kilns appear to have been constructed of mudbrick. These mudbrick kilns predate the period in question, however.

${ }^{78}$ Although all these small kilns are associated with the production of small wares, not all molded-ware production sites used these small kilns.

${ }^{79}$ These bricks (lateres) are the rectangular Sagalasssian lydion type. As this type is standardized in size, it is possible to determine an average length of ca. $0.484 \mathrm{~m}$ (Loots 2001, 147-48). The kiln was truncated across the upper part of a lydion-type brick (Loots 2001, 147-48), and it is conceivable that there were at least two originally, as a $0.48 \mathrm{~m}$ tall firing chamber is ab-
}

Kiln Contents: Vessel Dimensions and Stacking. Relative frequencies of vessel types used in the reconstruction were based on their proportional representation within each dump deposit. Types representing less than $1 \%$ of the total assemblage were omitted. Vessel diameters were recorded for each of the vessels, and the average of their horizontal dimensions was calculated. As few full profiles were preserved in the deposits, vertical heights were acquired from Poblome's Sagalassos Red Slip Ware typology. ${ }^{80}$ The stacking techniques used for each type were then reconstructed, based on the observations described in part 1 . In general, both deposits contained almost exclusively open forms that were stacked inside one another; in the later period, those stacks were placed into larger containers. In both deposits, general principles of stacking were consistent. Slightly in-turned rim forms were stacked higher, as the upper vessel sat atop the incurved rim of the lower vessel. Lopsided stacks of small cups were sometimes placed in larger vessels.

Once these techniques were identified, stacking calculations were made per vessel form. For each type of kiln spacer strip (see table 2; fig. 3), the distance between impression types was consulted to confirm the amount of space between the rims of vessels. Spacer strips and fused stacks of wasters also demonstrate that between two and 10 vessels were cinched by a single spacer strip. As previously stated, the two large container groups (i.e., the coarse ware Fabric 2 group and the Sagalassos Red Slip Ware Fabric 1 group) present different distributions of diameter ranges. Fabric 2 container diameters range from 22 to $45 \mathrm{~cm}$, and full profile heights from 29 to $43 \mathrm{~cm}$. Fabric 1 container diameters range from 14 to $35 \mathrm{~cm}$, and full profile heights from 12 to $25 \mathrm{~cm}$. Consequently, it would have been optimal to place larger bowls and platter forms, such as Types 1C140, 1B200, 1B210, and 1B220, in the larger coarse ware containers. These coarse ware containers appear to have been placed immediately atop the perforated oven floor, as they display patterns of extreme and highly localized heat exposure (i.e., vitrification), where the heat passing through the perforations affected the container. The Sagalassos Red Slip Ware lekanai were situated on top of the coarse wares in two courses, and individual, loose stacks filled the remaining kiln height.

Using these measurements and profile drawings of each of the vessel types, a scale model of the vessel

\footnotetext{
normally small in comparison with ethnographic examples.

${ }^{80}$ Supra n. 18.
} 
types and cylindrical kiln chamber was created using Autodesk Maya 2015 three-dimensional animation software (fig. 12). ${ }^{81}$ Using the model, the virtual vessels were then stacked inside the kiln space according to the methods and measurements outlined above. Multiple attempts were made to maximize the number of vessels packed into the kiln.

\section{Calculations and Considerations of Kiln Loads}

These calculations resulted in kiln-load counts of 1,708 vessels (with a typical range of $1,500-2,000$ vessels) for the second-century material and 398 vessels (with a typical range of 350-450 vessels) for the sixthcentury material. It should be explicitly stated that we do not claim that these quantities represent typical kiln loads from antiquity. What this exercise does offer, however, is a reconstruction based on a prescribed amount of kiln space and detailed identifications of stacking techniques for different vessel types in order to provide a general estimate (on an order of magnitude) for the impact that these changing styles and associated manufacturing techniques might have had on the economic operation of a workshop in different periods. Thus, within this kiln space of $1.1 \mathrm{~m}^{3}$, the two assemblages yielded a difference of more than 1,300 vessels, with roughly four times as many of the smaller, Roman-period vessels. Regardless of any ancient "tricks of the trade" that a modern reconstruction would have missed, this figure does generally represent the scale of the output difference and therefore highlights what was certainly a major change in workshop economics.

With far fewer vessels going into the kiln, the lower kiln loads of the later period likely had numerous implications concerning the relative costs (i.e., labor and raw materials) invested in each vessel's production. At the same time, while the additional space used by the containers in the kiln clearly resulted in fewer Sagalassos Red Slip Ware vessels per kiln load, the sagger-like, protective attributes of the containers presumably would have reduced the number of overfired wasters in each load, ${ }^{82}$ and thereby their use would have lowered the loss rate per firing. Moreover, as has been demonstrated, the repertoire of this period demonstrates less

\footnotetext{
${ }^{81}$ This model was prepared by Andrew Murphy and stacked by Elizabeth A. Murphy.

${ }^{82}$ This is assumed based on the observation that vitrification, so commonly found on the exterior walls and bases of the containers and incurred from exposure to high temperatures, only rarely penetrated through to the interior of the container, where the Sagalassos Red Slip Ware was stacked.
}

time and labor investment in the forming of the vessels (i.e., less trimming and more stamp use), which may have compensated for some of the increased costs of the firing. There is strong evidence to suggest that Sagalassos Red Slip Ware vessels were prepared in batches during the later period, and, as the larger containers were portable, they might also to some extent have been prestacked with batches of unfired tablewares outside the kiln. In this manner of prefilling kiln loads, a single kiln might more quickly be filled and fired, thereby resulting in higher cumulative output over time. Such factors may have helped compensate for the smaller number of vessels per kiln load in this later period. Yet even taking into account such cost-saving measures, it would seem unlikely that they would compensate for the dramatically smaller kiln loads and the greater quantities of clay and slip consumed in making the larger tablewares.

What little price evidence has been recorded for the Roman period suggests that pottery was generally conceived as a low-cost, affordable item, with red-glossed tablewares presumed to be slightly more expensive than other types of vessels. ${ }^{83}$ Yet this study suggests that, even within the same class of pottery manufacturing, costs might be significantly variable through time, and such expenses (at a cumulative scale) were likely to some extent passed on to distributors and consumers. If we couple this trend of increased per-vessel production costs with trends in Late Antique dining using larger (and potentially fewer) vessels, impacts on overall consumption patterns are conceivable. Such associations at this stage remain speculative, yet further work on tracing changing rates of consumption or frequencies of reuse and repair practices might offer evidence for the wider economic effects of these proposed cost trends.

\section{CONCLUSIONS}

This study has identified several important production factors that demonstrate the close relationship between consumption and production practices. While recent scholarship has provided important work on changing consumption patterns in the period and their effect on tableware styles, this study demonstrates just how intertwined such social changes are with economic practices in a workshop setting. Changing consumer fashions (associated with communal dining from large, open ceramic forms) appear to have influenced the choice of technical practices being employed

\footnotetext{
${ }^{83}$ Peña $2007,27-31$.
} 

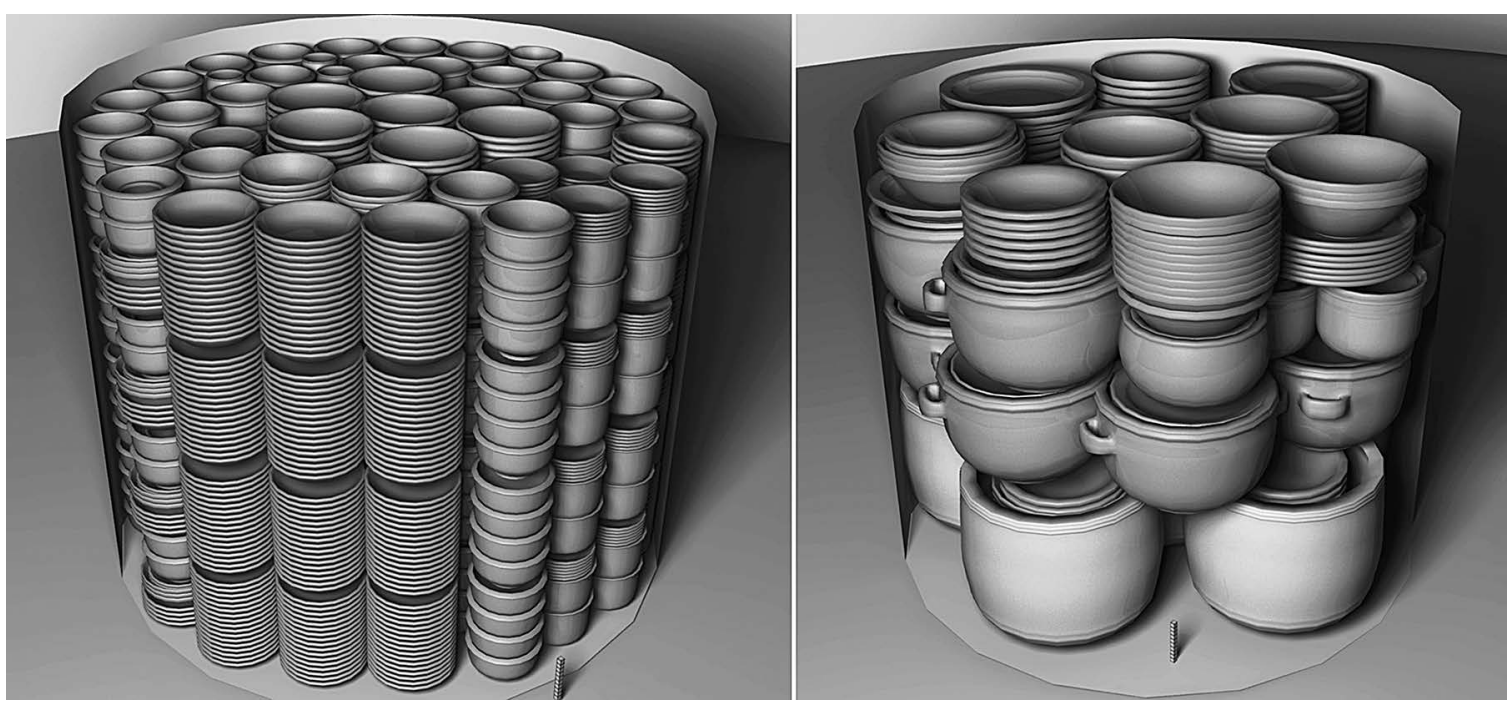

FIG. 12. Reconstructions of the early- (left) and late-period vessel (right) kiln-loading exercises. Model prepared by Andrew Murphy.

within the pottery workshops. In this sense, producing the large forms of the Late Antique period resulted in different manufacturing costs associated with each stage of production. Too often these changing technical styles have been interpreted within a framework of technological decline; this study, in contrast, demonstrates how technical choices serve to highlight the concerns and challenges facing the potter in manufacturing objects with particular sets of characteristics. Moreover, those changes in technological styles appear to have had dramatic implications for the organization and economics of production.

In the case of Sagalassos, if one were to look at the workshops, kilns, and clay types, one might get the impression that the industry showed remarkable continuity through time, and in these respects, it certainly did. This study highlights, however, that, even while maintaining these features through time, the Sagalassos Red Slip Ware industry did not operate in static ways through its duration. Rather, with renewed investment in the pottery industry of the Eastern Suburbium beginning in the second half of the fourth century C.E., the repertoire was changed to meet new consumption patterns, as were the technological styles practiced by the potters at work. Moreover, while this project specifically analyzed the material from Sagalassos, the results are not limited to this case study. As the stylistic trends observed in the material from Sagalassos reflect local production traditions interwoven with broader trends in tableware styles across the Mediterranean, this article raises some considerations on the nature of ceramic production and stylistic change in antiquity more widely.

Elizabeth A. Murphy

Institute for the Study of the Ancient World

New York University

15 East 84th Street

New York, New York 10028

Jeroen Poblome

University of Leuven

Blijde-Inkomststraat 21

3000 Leuven

Belgium

jeroen.poblome@kuleuven.be

\section{Works Cited}

Arthur, P. 2007. "Form, Function and Technology in Pottery Production from Late Antiquity to the Early Middle Ages." In Technology in Transition: A.D. 300-650, edited by L. Lavan, E. Zanini, and A. Sarantis, 159-86. Late Antique Archaeology 4. Leiden: Brill.

Barraud, D., M. Bonifay, F. Dridi, and J.-F. Pichonneau. 1998. "L'industrie céramique de l'Antiquité tardive." In Oudhna (Uthina): La redécouverte d'une ville antique de Tunisia, edited by H. Ben Hassan and L. Maurin, 139-67. Bordeaux: Ausonius.

Ben Moussa, M. 2007. La production de sigillées africaines: Recherches d'histoire et d'archeologie en Tunisie septentrionale et centrale. Barcelona: University of Barcelona Press.

Bonifay, M. 2004. Etudes sur la céramique romaine tardive d'Afrique. BAR-IS 1301. Oxford: Archaeopress. 
2007. "Ceramic Production in Africa During Late Antiquity: Continuity and Change." In Technology in Transition: A.D. 300-650, edited by L. Lavan, E. Zanini, and A. Sarantis, 143-58. Late Antique Archaeology 4. Leiden: Brill.

Bowman, A., and A. Wilson, eds. 2009. Quantifying the Roman Economy: Methods and Problems. Oxford: Oxford University Press.

Charleston, R.J. 1955. Roman Pottery. London: Faber and Faber.

Cool, H.E.M. 2006. Eating and Drinking in Roman Britain. Cambridge: Cambridge University Press.

Crane, H. 1988. "Traditional Pottery Making in the Sardis Region of Western Turkey.” Muqarnas 5:9-20.

Degeest, R. 2000. The Common Wares of Sagalassos. Studies in Eastern Mediterranean Archaeology3. Turnhout: Brepols.

Degryse, P., and J. Poblome. 2008. "Clays for Mass Production of Table and Common Wares, Amphorae and Architectural Ceramics at Sagalassos.” In Sagalassos. Vol. 6, Geo- and Bio- archaeology at Sagalassos and in Its Territory, edited by P. Degryse and M. Waelkens, 231-54. Leuven: Leuven University Press.

Degryse, P., J. Poblome, W. Viaene, H. Kucha, R. Ottenburgs, M. Waelkens, and J. Naud. 2008. "Provenancing the Slip of Sagalassos Red Slip Ware.” In Sagalassos. Vol. 6, Geo- and Bio- archaeology at Sagalassos and in Its Territory, edited by P. Degryse and M. Waelkens, 255-60. Leuven: Leuven University Press.

Dufä̈, B., Y. Barat, and S. Raux. 1997. Fabriquer de la vaisselle à l'époque romaine: Archéologie d'un centre du production céramique en Gaule La Boissière-École (Yvelines-France). Versailles: Service archéologique departmental des Yvelines.

Erdemgil, S., and S. Ozenir. 1982. "Preliminary Report on the Kilns Excavated in Ketios Valley.” RdA 6:109.

Fentress, E., and P. Perkins. 1987. “Counting African Red Slip Ware." In L'Africa romana: Atti del V convegno di studio Sassari, 11-13 dicembre 1987, edited by A. Mastino, 205-14. Sassari, Italy: University of Sassari.

Fentress, E., S. Fontana, R.B. Hitchner, and P. Perkins. 2004. "Accounting for ARS: Fineware and Sites in Sicily and Africa." In Side-by-Side Survey: Comparative Regional Studies in the Mediterranean World, edited by S.E. Alcock and J.F. Cherry, 147-62. Oxford: Oxbow.

Gadot, Y., and Y. Tepper. 2003. “The Late Byzantine Pottery Workshop at Khirbet Baraqa." TelAviv 30(1):130-62.

Greene, K. 1986. The Archaeology of the Roman Economy. Los Angeles: University of California Press.

Hawthorne, J. 1997. "Post Processual Economics: The Role of African Red Slip Ware Vessel Volume in Mediterranean Demography." In TRAC 96: Proceedings of the Sixth Annual Theoretical Roman Archaeology Conference, Sheffield 1996, edited by K. Meadows, C. Lemke, and J. Heron, 29-37. Oxford: Oxbow.

Hayes, J. 1997. Handbook of Mediterranean Roman Pottery. Norman: University of Oklahoma Press.

Hermann, J.J., and A. van den Hoek. 2002. Light in the Age of Augustine: Late Antique Ceramics from North Africa (Tunisia). Cambridge, Mass.: Harvard Divinity School.

Hope, C. 1978. "Dakhleh Oasis Project: Report on the Study of the Pottery and Kilns." The Journal of the Society for the Study of Egyptian Antiquities 9:187-201.

Hopper, R. 2000. Functional Pottery: Form and Aesthetic in Pots of Purpose. Iola, Wisc.: Krause Publications.

Hübner, G. 1993. Die Applikenkeramik von Pergamon: Eine Bildersprache im Dienst des Herrscherkultes. Pergamenische Forschungen 7. Berlin: Walter de Gruyter.

Hudson, N. 2006. "Dining in the Late Roman East.” Ph.D. diss., University of Minnesota.

Japp, S. 2014. "Sigillata of Pergamon-Eastern Sigillata C: Problems of Classification and Chronology." In Late Hellenistic to Mediaeval Fine Wares of the Aegean Coast of Anatolia: Their Production, Imitation and Use, edited by $\mathrm{H}$. Meyza and K. Domzalski, 10-21. Travaux de l'Institut des Cultures Méditerranéennes et Orientales de l'Académie Polonaise des Sciences 1. Warsaw: Neriton.

Kögler, P. 2014. "Table Ware from Knidos: The Local Production During the 2nd and 1st Centuries BC.” In Pottery, Peoples and Places: Study and Interpretation of Late Hellenistic Pottery, edited by P. Guldager Bilde and M.L. Lawall, 157-73. Black Sea Studies 16. Aarhus: Aarhus University Press.

Labrousse, M. 1980. "Circonscription de Midi-Pyrénées.” Gallia 38:464-69.

Laduron, D., and F. Depuydt. 1997. "Clay Raw Materials of Sagalassos Red Slip Ware: A Chronological Evaluation.” In Sagalassos. Vol. 4, Report on the Survey and Excavation Campaigns of 1994 and 1995, edited by M. Waelkens and J. Poblome, 507-18. Acta archaeologica Lovanensia Monographiae. Leuven: Leuven University Press.

Laubenheimer, F. 2001. "L'atelier de Sallèles d’Aude et son evolution dans le temps." In 20 ans de recheches à Sallèles d'Aude, edited by F. Laubenheimer, 11-24. Paris: Presses Universitaires Franc-Comtoises.

Lavan, L., E. Zanini, and A. Sarantis, eds. 2007. Technology in Transition: A.D. 300-650. Late Antique Archaeology 4. Leiden: Brill.

Lechtman, H. 1977. "Style in Technology: Some Early Thoughts." In Material Culture: Styles, Organization, and Dynamics of Technology, edited by H. Lechtman and R.S. Merrill, 3-20. St. Paul, Minn.: West Publishing.

Loots, L. 2001. "The Building Materials and Building Techniques at Sagalassos, Turkey.” Ph.D. diss., Katholieke Universiteit Leuven.

Lygouri-Tolia, E. 2000. “Evangelismo Station.” In Athens: The City Beneath the City. Antiquities from the Metropolitan Railway Excavations, edited by L. Parlama and N.C. Stampolidis, 209-15. Athens: Kapon Editions.

Mackensen, M. 1993. Die spätantiken Sigillata- und Lampentöpfereien von el Mahrine (Nordtunesien): Studien zur nordafrikanischen Feinkeramik des 4. bis 7. Jahrhunderts. Vol. 1, Text. Munich: C.H. Beck.

2009. “Technology and Organization of ARS Ware Production-Centres in Tunisia." In Studies on Roman Pottery of the Provinces of Africa Proconsularis and Byzacena (Tunisia): Hommage à Michel Bonifay, edited byJ.H. Humphrey, 17-44. JRA Suppl. 76. Portsmouth, R.I.: Journal of Roman Archaeology.

Mannoni, T. 2007. "The Transmission of Craft Techniques 
According to the Principles of Material Culture: Continuity and Rupture." In Technology in Transition: A.D. 300650, edited by L. Lavan, E. Zanini, and A. Sarantis, xli-lx. Late Antique Archaeology 4. Leiden: Brill.

Martens, F., B. Mušič, J. Poblome, and M. Waelkens. 2012. "The Integrated Urban Survey at Sagalassos." In Urban Landscape Survey in Italy and the Mediterranean, edited by F. Vermeulen, G.-J. Burgers, S. Keay, and C. Corsi, 84-93. Oxford: Oxbow.

Mees, A.W. 1995. Modelsignierte Dekorationen auf südgallischer Terra Sigillata. Forschungen und Berichte zur Vorund Frühgeschichte in Baden-Württemberg 54. Stuttgart: Theiss.

Murphy, E.A., and J. Poblome. 2012. "Situating Coroplast and Moulded-Ware Productions in Late Antique Sagalassos (SW Turkey)." Newsletter of the Coroplastic Studies Interest Group 7:2-3.

-2013. "Technical and Social Considerations of Tools from Roman Period Ceramic Workshops at Sagalassos (Southwest Turkey): Not Just Tools of the Trade?" JMA 25(2):197-217.

Ottenburgs, R., W. Viaene, R. Degeest, and M. Waelkens. 1995. "Statistical Analysis of Clays and Heterogeneous Sherds from Sagalassos." In Sagalassos. Vol. 3, Report on the Fourth Excavation Campaign of 1993, edited by M. Waelkens and J. Poblome, 255-70. Leuven: Leuven University Press.

Pallecchi, S. 2012. "I processi produttivi: Produttività, infornate, scarti." In Le fornaci romane di Giancola (Brindisi), edited by D. Manacorda and S. Pallecchi, 287-92. BibAr 27. San Spirito: Edipuglia.

Peacock, D.P.S., F. Bejaoui, and N. Ben Lazreg. 1990. "Roman Pottery Production in Central Tunisia.” JRA 3:59-84.

Peña, J.T. 2007. Roman Pottery in the Archaeological Record. Cambridge: Cambridge University Press.

.2009. "The Forming and Slipping of African Sigillata: Evidence from the Palatine East Assemblage.” In Studies on Roman Pottery of the Provinces of Africa Proconsularis and Byzacena (Tunisia): Hommage à Michel Bonifay, edited by J.H. Humphrey, 45-63. JRA Suppl. 76. Portsmouth, R.I.: Journal of Roman Archaeology.

Poblome, J. 1995. "The Ecology of Sagalassos (Southwest Turkey) Red Slip Ware." ActaArchLov 8:499-511.

_. 1997. "Decorated Handles of Sagalassos Red Slip Ware Found at Site L and Roman Silver Plate." In Sagalassos. Vol. 4, Report on the Survey and Excavation Campaigns of 1994 and 1995, edited by M. Waelkens and J. Poblome, 441-68. Leuven: Leuven University Press.

-1999. Sagalassos Red Slip Ware Typology and Chronology. Studies in Eastern Mediterranean Archaeology 2. Turnhout: Brepols.

2004. "Italian Sigillata in the Eastern Mediterranean." In Early Italian Sigillata: The Chronological Framework and Trade Patterns, edited by J. Poblome, P. Talloen, R. Brulet, and M. Waelkens, 17-30. Leuven: Peeters.

Poblome, J., M. Corremans, P. Bes, K. Romanus, and P. Degryse. 2008. "It Is Never Too Late ... The Late Roman Initiation of Amphora Production in the Territory of Saga- lassos.” In Eurgetes: Festschrift für Prof. Dr. Haluk Abbasoğlu zum 65. Geburtstag, edited by İ. Delemen, S. Çokay-Kepçe, A. Özdizbay, and Ö. Turak, 1001-13. Antalya: Suna \& İnan Kuraç Research Institute on Mediterranean Civilizations.

Poblome, J., B. Octavian, P. Degryse, W. Viaene, M. Waelkens, and S. Erdemgil. 2001. "The Sigillata Manufactories of Pergamon and Sagalassos.” JRA 14:143-65.

Poblome, J., R. Willet, N. Firat, F. Martens, and P. Bes. 2013. "Tinkering with Urban Survey Data: How Many Sagalassoses Do We Have?" In Archaeological Survey and the City, edited by P. Johnson and M. Millett, 146-74. Oxford: Oxbow.

Rice, P.M. 1987. Pottery Analysis: A Sourcebook. Chicago: The University of Chicago Press.

Rogl, C. 2003. "Späthellenistische Applikenkeramik und Verwandtes aus Ephesos.” ÖJh 72:187-206.

Rotroff, S. 1982. Hellenistic Pottery: Athenian and Imported Moldmade Bowls. Agora 22. Princeton: American School of Classical Studies at Athens.

Rotroff, S., and A. Oliver. 2003. The Hellenistic Pottery from Sardis: The Finds Through 1994. Cambridge, Mass.: Harvard University Press.

Rye, O.S. 1981. Pottery Technology: Principles and Reconstruction. Washington, D.C.: Taraxacum.

Rye, O.S., and C. Evans. 1976. Traditional Pottery Techniques of Pakistan: Field and Laboratory Studies. Smithsonian Contributions to Anthropology 21. Washington, D.C.: Smithsonian Institution Press.

Stone, D.L., L.M. Stirling, and N. Ben Lazreg. 1998. "Suburban Land-Use and Ceramic Production Around Leptiminus (Tunisia): Interim Report.” JRA 11:305-17.

Swift, E. 2007. "Decorated Vessels: The Function of Decoration in Late Antiquity." In Objects in Context, Objects in Use, edited by L. Lavan, E. Swift, and T. Putzeys, 385-409. Late Antique Archaeology 5. Leiden: Brill.

.2009. Style and Function in Roman Decoration: Living with Objects and Interiors. Burlington: Ashgate.

Uleners, H., and J. Poblome. 2014. "Sagalassos'ta Beklenmedik bir Keşif: Yeni bir Keramik Atölyesi/A New and Unexpected Potters' Workshop at Sagalassos.” ANMED Anadolu Akdenizi Arkeoloji Haberleri/News of Archaeology from Anatolia's Mediterranean Areas 12:87-94.

Vermoere, M., S. Six, J. Poblome, P. Degryse, E. Paulissen, M. Waelkens, and E. Smets. 2003. "Pollen Sequences from the City of Sagalassos (Pisidia, Southwest Turkey)." AnatSt 53:161-73.

Vroom, J. 2007. “The Archaeology of Late Antique Dining Habits in the Eastern Mediterranean: A Preliminary Study of the Evidence." In Objects in Context, Objects in Use, edited by L. Lavan, E. Swift, and T. Putzeys, 313-61. Late Antique Archaeology 5. Leiden: Brill.

Waelkens, M. 2011. “Sagalassos: Erste Stadt Pisidiens, Freund und Bundgenosse der Römer." AntW 3:62-71.

Ward-Perkins, B. 2006. The Fall of Rome and the End of Civilization. Oxford: Oxford University Press.

Wilson, A. 2009. “Approaches to Quantifying Roman Trade." In Quantifying the Roman Economy: Methods and Problems, edited by A. Bowman and A. Wilson, 213-49. Oxford: Oxford University Press. 